\title{
3 Research Square

\section{Transcriptome analysis of the sex pheromone gland and pheromone biosynthetic pathway in Eogystia hippophaecolus}

Ping Hu ( $\square$ hupingcs@163.com )

GuangXi University https://orcid.org/0000-0003-1713-063X

Dongbai Wang

Xingan vocational and technical college

Chenglong Gao

Beijing forestry university

Pengfei Lu

Beijing forestry university

Jing Tao

Beijing forestry university

Youqing Luo

Beijing Forestry university

\section{Research article}

Keywords: Pheromone biosynthesis, Acetyl-CoA carboxylase, Fatty acid synthase, Acyl-CoA desaturase, Acetyltransferase, Chemoreception protein

Posted Date: November 13th, 2019

DOI: https://doi.org/10.21203/rs.2.17249/v1

License: () (i) This work is licensed under a Creative Commons Attribution 4.0 International License. Read Full License 


\section{Abstract}

The moth Eogystia hippophaecolus (Hua et al.) is a major threat to sea buckthorn plantations in China. Specific and highly efficient artificial sex pheromone traps have been developed and used to control this pest species. However, the biosynthesis of sex pheromones Z7-14:Ac and E3-14:Ac remains poorly understood.Results We investigated the female pheromone gland transcriptome of E. hippophaecolus and identified two pheromone biosynthesis-activating neuropeptides (PBANs), two pheromone biosynthesisactivating neuropeptide receptors (PBANrs), five acetyl-CoA carboxylases (ACCs), six fatty acid synthases (FASs), 16 Acyl-CoA desaturases (DESs), 26 reductases (REDs), 13 acetyltransferases (ACTs), one fatty acid transport protein (FATP), one acyl-CoA-binding protein (ACBP), and five elongation of very long-chain fatty acid proteins (ELOS) in pheromone biosynthesis pathways. Additionally, we identified 11 odorantdegrading enzymes (ODEs) and 16 odorant-binding proteins (OBPs), 14 chemosensory proteins (CSPs), two sensory neuron membrane proteins (SNMPs), three odorant receptors (ORs), seven ionotropic receptors (IRs), and six gustatory receptors (GRs).Conclusions 77 unigenes involved in female pheromone biosynthesis, 31 chemoreception proteins and 11 odorant degradation enzymes were identified, which provided insight into the regulation of the pheromone components and pheromone recognition in the sex gland, and knowledge pertinent to new integrated pest management strategy of interference pheromone biosynthesis and recognition.

\section{Background}

Pheromone trapping of moths and other insects based on species-specific sex pheromone-elicited sexual communication and reproduction behaviors is important for integrated pest management practices worldwide. In moths, sex pheromones are multicomponent blends of C10-C18 long-chain unsaturated alcohols, aldehydes, and acetate esters produced and released through a modified fatty acid biosynthesis pathway in sex pheromone glands (PGs) which situate in the intersegmental membrane between the 8-9th abdominal segments in females [1-3]. Adult male moth antennae perceive female sex pheromone components from afar specifically, and this allows them to successfully locate females to initiate mating [4]. Among Lepidoptera, pheromone components largely differ between species, but some share the same components in different combinations, as demonstrated in Helicoverpa armigera and Helicoverpa assulta that participate in the mutual sex pheromone components Z11-16:Ald and Z9-16:Ald, although the ratio of them is contrary entirely (7:100 in H. assulta and 100:7 in H. armigera) [5-7]. In moths, multiple varying combinations of reactions produce distinct species-specific pheromone mixtures among different species, due to management of relevant sex pheromone enzymes, leading to speciation via changes in mate recognition systems [7].

Sex pheromone biosynthesis makes use of a revised fatty acid biosynthesis pathway $[1,8,9]$ which contains acetylation, desaturation, chain shortening, reduction, and oxidation by gland-specific enzymes processes, either separately or in combination variedly $[1,10]$. Pheromone biosynthesis-activating neuropeptides (PBANs) was released from the subesophageal ganglion and transportation to the PG, where they bind to a pheromone biosynthesis-activating neuropeptide receptor (PBANr), which is the first 
step of a characteristic moth pheromone biosynthetic pathway [11]. Then in turn activates functional group modification enzymes $[1,8,12,13]$ or acetyl-coenzyme A (CoA) carboxylase (ACC) [14]. The resulting signal triggers several enzyme pathways began by ACC that stimulates the conversion of acetyl-CoA to malonyl-CoA, leading to synthesize pheromone precursors (mostly 12,14, 16, or 18 carbon saturated fatty acids) [10]. NADPH and Malonyl-CoA are catalyzed by fatty acid synthases (FASs) to generate most saturated palmitic acid (16:0) and stearic acid (18:0) precursors with 16 and 18 carbon atoms, respectively, without double bonds [15-17]. Fatty acid transport proteins (FATPs) then transport these precursors into the PG, and double bonds are introduced at peculiar locations ( $\Delta 5$ [18], $\Delta 6$ [19], $\Delta 9$ [20, 21], $\Delta 10[22,23]$, $\Delta 11[24,25]$, and $\Delta 14$ [26]) by different desaturases (DESs), many of which were demonstrated by clone and expression in many moth species functionally [14,27], then $\beta$-oxidation shorten the chain [5]. The carboxyl carbon of formative unsaturated pheromone precursors with a specific chain length is modified by fatty acid reductase (FAR) enzymes to generate alcohols from fatty acyl precursors [28], which is oxidized to aldehydes in some species likely [29], or transformed to acetate esters (OAcs) by acetyltransferase (ACT) [30]. In addition to FATPs, acyl-CoA-binding proteins (ACBPs) have been demonstrated to work on production of the sex pheromone bombykol in Bombyx mori by in vivo RNA interference(RNAi) $[28,31]$. Besides DES and FAR $B$. mori are showed that are responsible for pheromone production by the same way [32-34]. However, other critical enzymes listed above, such as ACC, PBAN, and FAS, have not been demonstrated at the enzymatic level in insects.

Males have developed a subtle antennal olfaction system that can trace exceptionally small amounts of sex pheromone components which delivered from females in long distance [35]. The first step of olfactory recognition process involves in the abundant odorant-binding proteins (OBPs) and chemosensory proteins (CSPs) in the lymph of sensilla and pheromones and plant volatiles were binding, transported and solvated by them [36-39]. Pheromone-binding proteins (PBPs) are a subfamily of OBPs [40] that bind to pheromone compounds and participate in the pheromone recognition process. After capturing odors, transport odors and OBP-odor complexes were transported to four membrane receptor types: odorant receptors (ORs), gustatory receptors (GRs), ionotropic receptors (IRs), and sensory neuron membrane proteins (SNMPs), which are situated in the outer dendrites of olfactory receptor neurons. Depending on the different pheromones functional groups, aldehydes, alcohols, or esters, degradation involves specific enzymes in odor degradation pathways, such as multi-functional odorant-degrading enzymes (ODEs), pheromonedegrading enzymes (PDEs), and antennal esterases (AES).

In 2003, the sea buckthorn carpenterworm Eogystia hippophaecolus (Hua et al.) (Lepidoptera: Cossidae) destroy 66,500 ha of sea buckthorn Hippophae rhamnoides L. (Rosales: Elaeagnaceae) in western and northern China that stems soil erosion and desertification [41], besides this pest species can destroy Ulmus pumila L. (Urticales: Ulmaceae) and two or three species in Rosaceae [42]. Due to E. hippophaecolus with sophisticated ecological and life history traits, such as larvae bore into trunks and roots, and accomplish one generation among 3-4 years, there is no highly effective method for preventing damage to larvae, which is deemed a key danger to sea buckthorn plantations in China [43]. Sex pheromones of $E$. hippophaecolus female PGs (E)-3-tetradecenyl acetate (E3-14:Ac) and (Z)-7-tetradecenyl acetate (Z714:Ac) have been identified [44], which have been developed specific and efficient artificial sex pheromone 
traps [45]. And through the antennal transcriptome identified 137 olfactory genes including three PBPs, and found antennal biased expressed OBPs[46].

In the present study, we examined the female sex PG transcriptome of E. hippophaecolus, identified genes and enzymes related to pheromone biosynthesis, explored pheromone biosynthesis pathways, and identified putative genes related to chemoreception. Analysis of factors refered to the production of specific pheromones may provide insight into the regulation of the pheromone components, and hence the evolution of sexual communication in moth. Understanding interactions between pheromone biosynthesis and chemoreception genes in the sex PG and chemoreception genes in the antennae may reveal connections between pheromone biosynthesis in females and pheromone recognition in males, and provide knowledge pertinent to integrated pest management strategies.

\section{Results}

\section{Transcriptome sequencing and sequence assembly}

In total, we generated 28 million clean reads from a cDNA library of the female sex PG of $E$. hippophaecolus, of which $87.63 \%$ had q30 quality scores. After trimming adapters, removing low-quality raw sequences using Trimmomatic (http://www.usadellab.org/cms/index.php?page= trimmomatic), and splicing and assembly (using Trinity), we obtained 84,796 transcripts with an N50 of 2,021 bp and an average length of 1,068 bp, and 52,219 unigenes with an N50 of 1,410 bp (Figure 1). Raw reads have been deposited in the NCBI SRA database under GenBank accession numberPRJNA549033.

\section{Homology analysis and gene ontology annotation}

In all, 20,363 unigenes (39.00\%) were annotated with seven databases: 18,894 (92.79\%) were aligned to the NCBI non-redundant protein sequences $(\mathrm{Nr})$ database, 9,190 (45.13\%) were aligned to the Swiss-Prot database, 12,341 (60.63\%) were aligned to the protein family (Pfam) database, 11,905 (58.46\%) were aligned to the euKaryotic Orthologous Groups (KOG) database, 4,557 (22.38\%) were aligned to the Clusters of Orthologous Groups of proteins (COG) database, 10,304 (50.60\%) were aligned to the Gene Ontology (GO) database, and 8,803 (43.23\%) were aligned to the Kyoto Encyclopedia of Genes and Genomes (KEGG) database (Table 1). Interestingly, the greatest number of sequences matched B. mori $(7,077)$, followed by Danaus plexippus (5,530), Branchiostoma floridae (520), Papilio xuthus (385), Tribolium castaneum (318), Saccoglossus kowalevskii (316), Acyrthosiphon pisum (299), Solenopsis invicta (210), and Stegodyphus mimosarum (166). For the remaining $20.59 \%$ of sequences, we detected matches with loci in other insects (Figure 2).

We used GO annotations to classify the 10,304 unigenes into functional groups using BLAST2GO based on $p$-values calculated by hypergeometric distribution tests and E-values $<1 \times 10^{-5}$. In the E. hippophaecolus transcriptome, the biological process category accounted for the majority of GO annotations, followed by cellular component and molecular function. In the molecular function category, genes expressed in the PG 
were mostly related to binding, catalytic activity, and transporter activity, while cell part, cell, and organelle were the most enriched cellular component terms, and metabolic process was the most abundant molecular function subcategory (Figure 3a).

In total, 13,272 unigenes were classified into $25 \mathrm{KOG}$ categories, and unigenes related to general function prediction only $(2,712,20.43 \%)$ were the major KOG category, followed by signal transduction mechanisms $(1,904$ unigenes, $14.35 \%)$ and post-translational modification, protein turnover, and chaperones $(1,034$ unigenes, $7.79 \%$; Figure $3 b$ ).

\section{Identification of putative genes related to chemoreception and sex pheromone biosynthesis}

Homology searches identified members of gene subfamilies in the E. hippophaecolus PG transcriptome putatively involved in various biosynthetic processes, including pheromone production and chemoreception. A total of 77 genes potentially related to sex pheromone biosynthesis were identified, including two PBANs, two PBANrs, five ACCs, six FASs, 16 acyl-CoA desaturases (DESs), 26 reductases (REDs) comprising 19 FARs and seven aldo-keto reductases, 13 ACTs, one FATP, one ACBP, and five elongation of very long-chain fatty acid proteins (ELOs; Table 2). We also identified 11 pheromonedegrading proteins including five ODEs and six AESs (Table 3). In addition, 31 putative chemoreception genes were identified, including 16 OBPs with three new genes, 14 CSPs including one new gene, two known SNMPs, three known ORs, seven IRs including four new genes, and six GRs with five new genes, based on comparison with the established antennal transcriptome of E. hippophaecolus (Table 3). The transcriptome data also contained genes encoding proteins directly related to pheromones, including PBP and PR proteins. Among the top 100 unigenes based on fragments per kilobase of transcript per million mapped reads (FPKM) values, EhipOBP17 was $36^{\text {th }}$ and EhipCSP8, EhipCSP17, and EhipCSP6 were $72^{\text {nd }}$, $37^{\text {th }}$, and $20^{\text {th }}$, respectively (Additional file 1 ). All newly identified genes related to chemoreception are shown in bold font in Table 3. Sequences of all genes involved in pheromone biosynthesis and all new genes in chemoreception are listed in additional file 2.

\section{Phylogenetic analyses}

In order to assign putative functions to EhipDESs, EhipREDs, EhipODEs, EhipIRs, and EhipGRs, phylogenetic analyses were conducted for each group. A phylogenetic tree of DES sequences revealed three $\Delta 11$-desaturase orthologs including EhipDES3, and one $\Delta 9$-desaturase (Figure 4 ). A phylogenetic tree of REDs revealed two reductases: a FAR(yellow in Figure 5) and an aldo-keto reductase(blue in Figure 5). Both trees support the same cladogenesis, but the aldo-keto reductase clade includes EhipRED 6 and EhipRED 17 (Figure 5). In the ODE tree, ODEs and six AESs are disturbed in a disorderly manner (Additional file 3). The IR75 clade is most obvious in the IR tree, which contains EhipIR13 and EhipIR14 (Figure 6), named EhipIR75p1-1(13) and EhipIR IR75p1-2(14), and IR is functionally divided into IR68a, IR60a, IR7d, IR25a, IR8a, IR31a, IR41a, IR21a, and IR85a. 


\section{Discussion}

\section{Overview of the PG transcriptome}

The PG transcriptome of E. hippophaecolus was sequenced and analyzed. Among the identified 20,363 unigenes, only $50.60 \%$ were annotated to one or more $\mathrm{GO}$ terms, which indicated that massive $E$. hippophaecolus genes are either non-coding or share homology with genes not associated with GO terms, similar to the results of transcriptome analysis of the sex PG of Spodoptera litura [47], $\mathrm{H}$. armigera and $\mathrm{H}$. assulta [7], Plutella xylostella [48], Ephestia cautella [49], Agrotis ipsilon [50], Lutzomyia longipalpis [51], Heliothis virescens [52], and Agrotis segetum [53]. What's more, we identified 77 putative genes refered to sex pheromone biosynthesis in E. hippophaecolus, significantly more than the 55 identified in S. litura, [47], but fewer than the 87 in P. xylostella [48]. We also identified 31 chemoreception proteins in $E$. hippophaecolus, of which 13 were novel [46], and 11 ODEs. All in all, the results not merely offer a vital foundation for further elucidation of the molecular mechanisms of sex pheromone synthesis and metabolism, but also afford general perception into insect physiology and the exploitation of novel pest control strategies [54].

\section{Genes involved in the sex pheromone biosynthesis pathway}

\section{Pheromone biosynthesis-activating neuropeptide receptor (PBANr)}

In the PG of E. hippophaecolus, we identified two PBANr and two PBAN genes. Only four alternative splice transcripts of PBANr isoforms (A, B, and C) with diversities in C-terminal sequences have been reported for a single insect species [55]. PBAN receptor isoforms $B$ and $C$ have been characterized from $O$. nubilalis [56] and $H$. virescens [57] functionally, and isoforms $C$ and $B$ were identified in the $P G$ of $E$. hippophaecolus in the present work, both presumably involved in pheromone production. Analysis of the PG transcriptomes of $A$. segatum [58] and $H$. virescens [52] revealed a $\mathrm{G}$ protein gamma subunit homolog, the diapause hormone receptor, that interacts with PBANr.

\section{Acetyl-CoA carboxylase (ACC)}

ACC catalyzing the production of malonyl-CoA from acetyl-CoA is the first committed and rate restrictive biosynthetic step in start pheromone biosynthesis $[10,59]$. In the E. hippophaecolus PG, we identified five transcripts encoding ACCs expressed at relatively low levels.

\section{Fatty acid synthase (FAS)}

FAS is believed to facilitate the transformation of malonyl-COA and NADPH to generate saturated fatty acids (16:acyl in E. hippophaecolus) [49]. We identified six FAS unigenes in the E. hippophaecolus PG, 
among which EhipFAS3 has the longest open reading frame (ORF) and is expressed at distinct high levels (FPKM = 913), suggesting that it may be the main FAS.

\section{Fatty acid transport protein (FATP)}

The evolutionarily conserved membrane-bound proteins family FATPs promote the ingestion of extracellular long-chain fatty acids (LCFAs), and/or very LCFAs, and facilitate the ATP-dependent esterification of these fatty acids to their corresponding acyl-CoA derivatives [60]. In E. hippophaecolus, we identified one FATP, the function of which has been showed by in vitro expression and knockdown analysis in B. mori [60] and Eilema japonica [61].

\section{Acyl-CoA desaturase (DES)}

Moth sex pheromones typically include double bonds introduced by desaturases at specific locations in the fatty acyl carbon chains $[25,62,63]$. Newly in some Lepidoptera species, several reductase gene family have been discovered and functionally characterized, including Heliothis virescens, Heliothis subflexa, $H$. armigera and $\mathrm{H}$. assulta [65], Ostrinia scapulalis [64], Yponomeuta evonymellus (L.), Yponomeuta padellus (L.), and Yponomeuta rorellus (Hübner) [31], and Ostrinia nubilalis [66]. Sixteen putative sex pheromone components extracted from the E. hippophaecolus PG were unsaturated fatty acids with $£ 16$ carbons and acetate as the functional group. Notably, Z7-14:Ac and E3-14:Ac were previously identified as pheromones in E. hippophaecolus [44], and C16 fatty acids require $\beta$-oxidation to form short-chain $\mathrm{C} 14$ fatty acids, but $\beta$-oxidation enzymes were not identified in the E. hippophaecolus transcriptome. Female sex pheromones in the E. hippophaecolus PG have been identified as Z7-14:Ac and E3-14:Ac [44]. It is therefore rational to suggest that the saturated fatty acid precursor of E. hippophaecolus sex pheromones may be palmitic acid (16:0), which is desaturated by $\triangle 11$-desaturase to constitute the precursor Z11-16:acyl-CoA for the production of two major components (Z7-14:OAc and E3-14:OAc; Figure 7). Other studies in Lepidoptera species indicate that a $\Delta 11$-desaturase acting on palmitic acid leads to the production of the sex pheromone components $[67,68]$. In the E. hippophaecolus PG transcriptome, we identified three $\Delta 11$ desaturases, three $\Delta 9$-desaturases, and one $\Delta 4$-desaturase, and based on the DES phylogenetic tree, EhipDES3 is another $\Delta 11$-desaturase named Ehip $\Delta 11 \mathrm{DES}-4$.

\section{Fatty acyl-CoA reductase (FAR)}

Through a specific $\Delta 11$ double bond brought in fatty acid precursors a fatty acyl-CoA precursor was formed, which is then shortened sequentially by $\beta$-oxidation for formation different shorter chain fatty acylCoA precursors [1] that are further lessened separately by FAR for formation corresponding fatty alcohols $[31,69]$. We identified 19 FAR unigenes. Since the discovery of their ability to reduce fatty acids to alcohols in $B$. mori [19], these enzymes have also been functionally characterized in Ostrinia spp. [28, 66], Yponomeuta spp. [31], Helicoverpa spp., and Heliothis spp. [65]. FARs from Spodoptera exigua exhibit a preference for $\mathrm{C} 14$ and $\mathrm{C} 16$ fatty acid substrates [70].

\section{Acetyltransferase (ACT)}


In E. hippophaecolus, sex pheromone mixtures only contain acetates which are intermediates that are acetylated to acetate esters by ACTs [71]. In the present study, we identified 12 ACT unigenes. However, ACT enzymes that have not been verified functionally are postulated to be participated in the sex pheromone biosynthesis pathway. We identified only one ACBP gene, and its counterpart is expressed in the $B$. mori PG mainly, suggesting that ACBP takes vital effect on the production of sex pheromones adjusted by the neurohormone PBAN [72]. The proposed biosynthesis pathway for Z7-14:Ac and E3-14:Ac in E. hippophaecolus is shown in Figure 7.

\section{Genes involved in chemoreception}

Moth ovipositors have chemoreceptive sensilla $[73,74]$, and the sex PG expresses chemoreception proteins such as OBPs and CSPs that are postulated to facilitate the transportation of sex pheromones. OBPs are in the first gate of the odorant recognition process, which combine and transport especially for hydrophobic odorant molecules, including plant volatiles and pheromones across the lymph in the sensillum [75]. We identified 16 OBPs, including three new genes not previously identified in the antennae of $E$. hippophaecolus, in which EhipOBP2, EhipOBP4, EhipOBP5, and EhipOBP8 are expressed in male antennae, while EhipOBP1 and EhipOBP6 are expressed in the foot and external genitals, respectively [46]. EhipPBP3 was the second most abundant of the three PBPs in male antennae at both gene and protein expression levels [76]. The subfamily of OBPs, CSPs reveal diverse expression profiles with OBPs. OBP expression is antennae-biased, but CSPs are without obvious expression preference [77]. We identified 14 OBPs, including one new CSP not previously identified, in the antennae of E. hippophaecolus [46]. ORs couple binding proteins with olfactory sensory neurons and conduct olfactory signal transduction. In female and male antennae, we detected three known ORs, including the pheromone receptor EhipPR2 [46]. We identified seven IRs, including four novel genes [46]. Genome-wide analysis of IRs in Heliconius butterflies has been carried out [78], and the results of dendrogram analysis were consistent with their corresponding functions. Specifically, we identified EhipIR13 and EhipIR14 in the IR75 clade, which suggests that EhipIR13 and EhipIR14 are other types of EhipIR75p1, named EhipIR75p1-1(13) and EhipIR IR75p12(14).Notably IR8a and IR25a are considered function as IR co-receptors [79, 80], and also identified in the PG transcriptome. We also detected six GRs, including five new genes, and two known SNMPs [46] that are conserved throughout holometabolous insects [81, 82]. IRs are a conserved family of synaptic ligand-gated ion channels that evolved from ionotropic glutamate receptors (iGluRs) $[79,80]$, which are refered to both insects' smell and taste process [83, 84]. Mutations of IR64a, IR84a, IR25a, and IR8a in Drosophila restrain odorant-evoked neuronal responses $[85,86]$. However, the specificity of ligand recognition by IRs is unclear [83]. Intriguingly, Drosophila IR94b is functionally involved in auditory system [87]. Five ODEs and six AES enzymes were identified in the PG transcriptome, all of which are new in E. hippophaecolus [46].

In summary, the female PG expresses OBPs, CSPs, ORs, IRs, GRs, SNMPs, and ODEs that together may mediate pheromone biosynthesis and recognition. Analysis of pheromone biosynthesis and chemoreception genes in the PG and antennae of E. hippophaecolus can reveal details of pheromone 
biosynthesis, chemoreception, and transport and degradation mechanisms, which may elucidate connections between pheromone biosynthesis in females and pheromone recognition in male antennae.

\section{Conclusion}

Herein, we investigated the E. hippophaecolus sex PG transcriptome, in which we identified 77 unigenes involved in female pheromone biosynthesis, providing a foundation for further elucidation of the molecular mechanisms of sex pheromone biosynthesis. Additionally, 31 chemoreception proteins were identified, including 13 new genes, along with 11 novel odorant degradation enzymes, indicating that pheromone recognition may occur in the sex gland. The pheromone biosynthesis pathway and chemoreception results reveal putative connections between pheromone biosynthesis in females and pheromone recognition in male antennae, and provide knowledge that may be applicable for developing the future integrated pest management strategy of interference pheromone biosynthesis and recognition.

\section{Methods}

\section{Ethics statement}

The seabuckthorn carpenterworm Eogystia hippophaecolus(Lepidoptera: Cossidae) is a common forestry pest in China, which collections were made with the direct permission of Jianping forestry bureau. All operations were performed according to ethical guidelines in order to minimize pain and discomfort to the insects.

\section{Insect and tissue collection}

E. hippophaecolus were collected from damaging seabuckthorn forest by light during middle of June to end of July 2015 to 2016 in Jianping, Liaoning, China. Female sexual glands were excised and stored in RNAlater (Ambion, Austin, TX, USA)(Figure 8). Then all samples were taken back indoor and stored at $-80^{\circ} \mathrm{C}$.

\section{cDNA library construction and Illumina sequencing}

We extracted total RNA from sexual glands of E. hippophaecolus utilization TRIzol reagent (Ambion) and the RNeasy Plus Mini Kit (No. 74134; Qiagen, Hilden, Germany) abiding by the manufacturer's instructions. Using NanoDrop 8000 (Thermo, Waltham, MA, USA) detected RNA quantity. RNA of female sexual glands was used to construct three cDNA libraries respectively. Construction cDNA libraries and Illumina sequencing of samples were implemented at CapitalBio Corporation (Beijing, China). Using TruSeq RNA Sample Preparation Kit v2-Set A (No. RS-122-2001; Illumina, San Diego, CA, USA) performe purification and fragmentation of mRNA samples. The first-strand cDNA were synthesized by utilization random hexamer primers, then using RNase $\mathrm{H}$, dNTPs, buffer, and DNA polymerase I at $16^{\circ} \mathrm{C}$ for $1 \mathrm{~h}$ to synthesize the second-strand CDNA. After end repair, A-tailing, and the ligation of adaptors, the products were amplified by PCR and quantified precisely by the Qubit DNA Br Assay Kit (Q10211; Invitrogen, Carlsbad, CA, USA). cDNA 
library were obtained after they were purified by the MinElute Gel Extraction Kit (Qiagen, Cat No. 28604). On the HiSeq2500 platform three cDNA libraries were sequenced.

\section{Assembly and functional annotation}

All low quality and adaptor sequences in all raw reads were removed by Trimmomatic (http://www.usadellab.org/cms/index.php?page=trimmomatic) to get clean reads. Clean reads assembly was implemented by Trinity (Version: r2018-07-31) with the default parameters. The largest alternative splicing variants in the Trinity results were unigenes.

The annotation of unigenes was in seven databases which include NCBI non-redundant protein sequences (Nr), Protein family (Pfam), Swiss-Prot, Kyoto Encyclopedia of Genes and Genomes (KEGG), and Gene Ontology (GO). For the putative protein sequences, we performed blastx search against the $\mathrm{Nr}$ database (http://www.ncbi.nlm.nih.gov/genbank/), Swiss-Prot (http://www.uniprot.org/), Groups of KEGG database (http:// www.genome.jp/kegg/pathway.html) with an e-value cut-off of 1.0E-5. Pfam (http://pfam. sanger.ac.uk/) were searched by HMMER 3.0 package[88] with e-value of 1.0E-10. BLAST2GO was used to obtain Gene Ontology (GO) annotation of assembled unigenes for describing cellular component, molecular function, and biological process with an E value cut-off of 1.0E-5[89]. NCBI ORF Finder tool (http://www.ncbi.nlm.nih.gov/gorf/gorf.html) searched the longest ORF for each unigene. FPKM values (fragments per kilobase per million reads) was used to evaluate the expression levels [90], which was calculated by RSEM (RNA-Seq by Expectation-Maximization)(Version: v1.2.6)with default parameters[91].

\section{Identification of candidate genes involved in E. hippophaecolus pheromone biosynthesis}

Genes and enzymes involved in moth sex pheromone production have been reported previously, such as in B. mor[12, 60], E. cautella[49], Chilo Suppressalis[92], H. virescens[52], A. ipsilon[50], S. litura[47] and $P$. xylostella[48]. We focused our research on the target genes: (1) Pheromone biosynthesis activating neuropeptide (PBAN); (2) Acetyl-CoA carboxylase (ACC); (3)Fatty acid synthase(FAS); (4)Desaturase(DES); (5)Fatty acyl reductase(RED, contain FAR).

\section{Identification of putative genes involved in fatty acid transport and pheromone degradation}

A FATP was identified from the PG of $B$. mori [60]. We performed BLASTx to authenticate $E$. hippophaecolus FATP genes. Besides we focus on Acetyltransferase (ACT); Acyl-CoA binding protein(ACBP) and elongation of very long chain fatty acids protein(ELO) based on previous study. Since the sex pheromone E. hippophaecolus is comprised of Z7-14:Ac and E3-14:Ac, the earlier reports that esterases, for example odorant degrading enzyme(ODE) and antennal esterase(AES), may take vital effect on pheromone degradation $[93,94]$. Therefore, we performed BLASTx to authenticate candidate esterase genes in the E. hippophaecolus pheromone gland NGS dataset.

\section{Identification of putative genes involved in pheromone transport}


With BLASTx, the available sequences of OBPs, CSPs, ORs, GRs, IRs, SNMPs and ODEs proteins from insect species were used as queries to authenticate candidate unigenes refered to olfaction in $E$. hippophaecolus from Nr, Pfam and Swiss-Prot database. All candidate OBPs, CSPs, ORs, GRs, IRs, and SNMPs were manually verified by tBLASTn in NCBI online evaluating the BLASTx results. Then compared the putative genes involved in pheromone transport in PG transcriptome with chemosensory genes in antennal transcriptome of E. hippophaecolus[46].

\section{Phylogenetic analysis}

Amino acid sequence alignment was implemented using Muscle method implemented in Mega v6.0 software package[95]. Using the neighbor-joining (NJ) method[96] with P-distances model and a pairwise deletion of gaps constructed the phylogenetic tree. The dependability of the tree structure and node support was valued by bootstrap analysis with 1000 replicates. The phylogenetic trees were colored and arranged in FigTree (Version 1.4.2). The phylogenetic analyses of DESs was based on 16 amino sequences of DESs of E. hippophaecolus, 21 DESs of B. mori, 4 of A. ipsilon, 9 of A. segetum, 8 of $H$. armigera, 5 of 0 . nubilalis, 7of 0 . furnacalis, 2 of 0 . latipennis and 4 of Drosophila melanogaster. ODEs tree was based on 5 ODEs and 6 AESs of E. hippophaecolus, 23AESs of C. suppressalis, 2 of B. mori, 12 AESs of Cydia pomonella, 10DEs of Conogethes punctiferalis and Antheraea polyphemus, 16 ODEs of Sesamia inferens, 7 ODEs of Operophtera brumata, and 2 of D. melanogaster. REDs tree were based on 19FARs and 7REDs of E. hippophaecolus, 2 REDs and 2 FARs of $D$. melanogaster, 10REDs and 3 FARs of $A$. ipsilon, 5 FARs of $A$. segetum, 12 REDs and 15FARs of $B$. mori, 1 REDs and 6 FARs of $H$. armigera and 9 FARs of 0 . furnacalis, IRs tree was constructed by 3 IRs of $H$. armigera, 7 IRs of E. hippophaecolus, 35 of D. melanogasterand Van Schooten used IRs of M. sexta, B. mori, D. plexippus, and H. Melpomene[78]. Accession number of chemosensory proteins in tree without reference was in additional file 4.

\section{Abbreviations}

CSPs: Chemosensory proteins; DEET: N,N-diethyl-meta-toluamide; GO: Gene Ontology; GPCRs: G proteincoupled receptors; GRs: Gustatory receptors; IRs: Ionotropic receptors; iGluRs: ionotropic glutamate receptors OBPs: Odorant binding proteins; ORFs $₫$ Open reading frame; ORs: Odorant receptors; Orco: Odorant receptor co-receptor; ORNs: Olfactory receptor neuron; PR: pheromone receptor; SNMPs: Sensory neuron membrane proteins. ODEs: odorant degrading enzymes. PBAN: pheromone biosynthesis activating neuropeptide, PBANr: pheromone biosynthesis activating neuropeptide receptor, ACC: acetyl-CoA carboxylase, FAS: fatty acid synthase, DES : Acyl-CoA desaturase, RED: reductase, FAR: fatty-acyl-CoA reductase , ACT: acetyltransferase, FATP: fatty acid transport protein, ACBP: acyl-CoA binding protein, ELO: elongation of very long chain fatty acids protein, PG: sex pheromone gland

\section{Declarations}

\section{Ethics approval and consent to participate}


The seabuckthorn carpenterworm Eogystia hippophaecolus(Lepidoptera: Cossidae) is a common forestry pest in China, which collections were made with the direct permission of Jianping forestry bureau. All operations were performed according to ethical guidelines in order to minimize pain and discomfort to the insects.

\section{Consent to publish}

All authors and organization with relationship with collection Eogystia hippophaecolus consent to publish the manuscript.

\section{Availability of of data and materials}

All supporting data is included within the article and its additional files.

\section{Competing interests}

No competing interests and financial competing interests.

\section{Funding}

This work was supported by the Beijing's Science and Technology Planning Project (Grant No. Z171100001417005) and Natural Science Foundation of Inner Mongolia (Grant No. 2018BS03010). Beijing's Science and Technology Planning Project supported the fee of collection and analysis of this study, and Natural Science Foundation of Inner Mongolia supported the fee of analysis and interpretation of the manuscript.

\section{Authors' contributions}

Ping Hu carried out the molecular genetic studies, performed the sequence alignment, experiments and drafted the manuscript. Dongbai Wang and Chenglong Gao collected almost all samples and participated in some experiments. Chenglong Gao participated in all experiments. Pengfei Lu, Jing Tao and Youqing Luo designed and conceived of the study; Jing Tao and Youqing Luo also helped to draft the manuscript. All authors read and approved the final manuscript.

\section{Acknowledgments}

We thank Liansheng Zhang and Yunbo Ma for animal collection.

\section{References}

1. Jurenka R: Insect pheromone biosynthesis. In: The chemistry of pheromones and other semiochemicals I. Springer, 2004: 97-132.

2. Roelofs WL, Rooney AP: Molecular genetics and evolution of pheromone biosynthesis in Lepidoptera. Proceedings of the National Academy of Sciences 2003, 100(16):9179-9184. 
3. Cardé RT, Haynes KF: Structure of the pheromone communication channel in moths. Advances in insect chemical ecology 2004:283-332.

4. Wyatt TD: Fifty years of pheromones. Nature 2009, 457(7227):262.

5. Wang H-L, Zhao C-H, Wang C-Z: Comparative study of sex pheromone composition and biosynthesis in Helicoverpa armigera, H. assulta and their hybrid. Insect biochemistry and molecular biology 2005, 35(6):575-583.

6. Wu H, Hou C, Huang L-Q, Yan F-S, Wang C-Z: Peripheral coding of sex pheromone blends with reverse ratios in two Helicoverpa species. PloS one 2013, 8(7):e70078.

7. Li Z-Q, Zhang S, Luo J-Y, Wang C-Y, Lv L-M, Dong S-L, Cui J-J: Transcriptome comparison of the sex pheromone glands from two sibling Helicoverpa species with opposite sex pheromone components. Scientific reports 2015, 5:9324.

8. Tillman JA, Seybold SJ, Jurenka RA, Blomquist GJ: Insect pheromones-an overview of biosynthesis and endocrine regulation. Insect biochemistry and molecular biology 1999, 29(6):481-514.

9. Matsumoto S: Molecular mechanisms underlying sex pheromone production in moths. Bioscience, biotechnology, and biochemistry 2010, 74(2):223-231.

10. Volpe J, Vagelos P: Saturated fatty acid biosynthesis and its regulation. Annual Review of Biochemistry 1973, 42(1):21-60.

11. Zhu J, Millar J, Löfstedt C: Hormonal regulation of sex pheromone biosynthesis in the turnip moth, Agrotis segetum. Archives of insect biochemistry and physiology 1995, 30(1):41-59.

12. Matsumoto S, Hull JJ, Ohnishi A, Moto Ki, Fónagy A: Molecular mechanisms underlying sex pheromone production in the silkmoth, Bombyx mori: characterization of the molecular components involved in bombykol biosynthesis. Journal of insect physiology 2007, 53(8):752-759.

13. Matsumoto S, Ohnishi A, Lee JM, Hull JJ: Unraveling the pheromone biosynthesis activating neuropeptide (PBAN) signal transduction cascade that regulates sex pheromone production in moths. In: Vitamins \& Hormones. vol. 83: Elsevier; 2010: 425-445.

14. Blomquist G, Jurenka R, Schal C, Tittiger C: Pheromone production: biochemistry and molecular biology. In: Insect endocrinology. Elsevier; 2012: 523-567.

15. Bjostad LB, Roelofs WL: Biosynthesis of sex pheromone components and glycerolipid precursors from sodium [1-14 C] acetate in redbanded leafroller moth. Journal of chemical ecology 1984, 10(4):681691.

16. Tang JD, Charlton RE, Jurenka RA, Wolf WA, Phelan PL, Sreng L, Roelofs WL: Regulation of pheromone biosynthesis by a brain hormone in two moth species. Proceedings of the National Academy of Sciences 1989, 86(6):1806-1810.

17. Jurenka RA, Jacquin E, Roelofs WL: Control of the pheromone biosynthetic pathway in Helicoverpa zea by the pheromone biosynthesis activating neuropeptide. Archives of insect biochemistry and physiology 1991, 17(2-3):81-91.

18. Foster S, Roelofs W: Sex pheromone biosynthesis in the tortricid moth, Ctenopseustis herana (Felder \& Rogenhofer). Archives of Insect Biochemistry and Physiology: Published in Collaboration with the 
Entomological Society of America 1996, 33(2):135-147.

19. Wang H-L, Liénard MA, Zhao C-H, Wang C-Z, Löfstedt C: Neofunctionalization in an ancestral insect desaturase lineage led to rare $\Delta 6$ pheromone signals in the Chinese tussah silkworm. Insect biochemistry and molecular biology 2010, 40(10):742-751.

20. Albre J, Liénard MA, Sirey TM, Schmidt S, Tooman LK, Carraher C, Greenwood DR, Löfstedt C, Newcomb RD: Sex pheromone evolution is associated with differential regulation of the same desaturase gene in two genera of leafroller moths. PLoS genetics 2012, 8(1):e1002489.

21. Martinez T, Fabrias G, Camps F: Sex pheromone biosynthetic pathway in Spodoptera littoralis and its activation by a neurohormone. Journal of Biological Chemistry 1990, 265(3):1381-1387.

22. Hao G, Liu W, O’Connor M, Roelofs W: Acyl-CoA Z9-and Z10-desaturase genes from a New Zealand leafroller moth species, Planotortrix octo. Insect biochemistry and molecular biology 2002, 32(9):961966.

23. Foster S, Roelofs W: Sex pheromone biosynthesis in the leafroller moth Planotortix excessana by $\Delta 10$ desaturation. Archives of insect biochemistry and physiology 1988, 8(1):1-9.

24. Liénard MA, Lassance J-M, Wang H-L, Zhao C-H, Piškur J, Johansson T, Löfstedt C: Elucidation of the sex-pheromone biosynthesis producing 5, 7-dodecadienes in Dendrolimus punctatus (Lepidoptera: Lasiocampidae) reveals $\Delta 11$-and $\Delta \mathbf{9}$-desaturases with unusual catalytic properties. Insect biochemistry and molecular biology 2010, 40(6):440-452.

25. Ding B-J, Carraher C, Löfstedt C: Sequence variation determining stereochemistry of a $\Delta 11$ desaturase active in moth sex pheromone biosynthesis. Insect biochemistry and molecular biology 2016, 74:6875.

26. Roelofs WL, Liu W, Hao G, Jiao H, Rooney AP, Linn CE: Evolution of moth sex pheromones via ancestral genes. Proceedings of the National Academy of Sciences 2002, 99(21):13621-13626.

27. Rafaeli A: Mechanisms involved in the control of pheromone production in female moths: recent developments. Entomologia experimentalis et applicata 2005, 115(1):7-15.

28. Lassance J-M, Liénard MA, Antony B, Qian S, Fujii T, Tabata J, Ishikawa Y, Löfstedt C: Functional consequences of sequence variation in the pheromone biosynthetic gene pgFAR for Ostrinia moths. Proceedings of the National Academy of Sciences 2013, 110(10):3967-3972.

29. Teal P, Tumlinson J: The role of alcohols in pheromone biosynthesis by two noctuid moths that use acetate pheromone components. Archives of insect biochemistry and physiology 1987, 4(4):261-269.

30. Roelofs WL, Wolf WA: Pheromone biosynthesis in Lepidoptera. Journal of chemical ecology 1988, 14(11):2019-2031.

31. Liénard MA, Hagström ÅK, Lassance J-M, Löfstedt C: Evolution of multicomponent pheromone signals in small ermine moths involves a single fatty-acyl reductase gene. Proceedings of the National Academy of Sciences 2010, 107(24):10955-10960.

32. Moto Ki, Kojima H, Kurihara M, Iwami M, Matsumoto S: Cell-specific expression of enhanced green fluorescence protein under the control of neuropeptide gene promoters in the brain of the silkworm, 
Bombyx mori, using Bombyx mori nucleopolyhedrovirus-derived vectors. Insect biochemistry and molecular biology 2003, 33(1):7-12.

33. Moto Ki, Suzuki MG, Hull JJ, Kurata R, Takahashi S, Yamamoto M, Okano K, Imai K, Ando T, Matsumoto S: Involvement of a bifunctional fatty-acyl desaturase in the biosynthesis of the silkmoth, Bombyx mori, sex pheromone. Proceedings of the National Academy of Sciences 2004, 101(23):86318636.

34. Ohnishi A, Hull JJ, Matsumoto S: Targeted disruption of genes in the Bombyx mori sex pheromone biosynthetic pathway. Proceedings of the National Academy of Sciences 2006, 103(12):4398-4403.

35. Vogt RG: Molecular basis of pheromone detection in insects. Comprehensive insect physiology, biochemistry, pharmacology and molecular biology 2005, 3:753-804.

36. Pelosi P, Zhou J-J, Ban L, Calvello M: Soluble proteins in insect chemical communication. Cellular and Molecular Life Sciences CMLS 2006, 63(14):1658-1676.

37. Ban L, Zhang L, Yan Y, Pelosi P: Binding properties of a locust's chemosensory protein. Biochemical and biophysical research communications 2002, 293(1):50-54.

38. Kaissling KE: Olfactory perireceptor and receptor events in moths: a kinetic model. Chemical senses 2001, 26(2):125-150.

39. Leal WS, Chen AM, Ishida Y, Chiang VP, Erickson ML, Morgan TI, Tsuruda JM: Kinetics and molecular properties of pheromone binding and release. Proceedings of the National Academy of Sciences of the United States of America 2005, 102(15):5386-5391.

40. Zhou J-J: Chapter ten-Odorant-binding proteins in insects. Vitamins \& Hormones 2010, 83:241-272.

41. Marchal E, Badisco L, Verlinden H, Vandersmissen T, Van Soest S, Van Wielendaele P, Broeck JV: Role of the Halloween genes, Spook and Phantom in ecdysteroidogenesis in the desert locust, Schistocerca gregaria. Journal of insect physiology 2011, 57(9):1240-1248.

42. Zong SX LY, Lu CK, Xu ZC, Zhang LS: Prelininary Study on Biological Characteristic of Holcocerus hippophaecolus. Scientia Silvae Sinicae 2006, 41:6.

43. Zong S, Jia F, Lu Y, Xu Z, Zhang L, Liang S: Harm characteristics and population dynamics of Holcocerus hippophaecolus. J Beijing Forest Univ 2005, 27:5.

44. Fang Y-L, Sun J-H, Zhao C-H, Zhang Z-N: Sex pheromone components of the sandthorn carpenterworm, Holcocerus hippophaecolus. Journal of chemical ecology 2005, 31(1):39-48.

45. Shixiang Zong JZ, Youqing Luo, Liansheng Zhang, Guolong Yao, Delu Zong: Application sex pehromone lures for monitoring and controling the seabuckthorn moth Chinese Bulletin of Entomology 2010, 47(6):4.

46. Hu P, Tao J, Cui M, Gao C, Lu P, Luo Y: Antennal transcriptome analysis and expression profiles of odorant binding proteins in Eogystia hippophaecolus (Lepidoptera: Cossidae). BMC genomics 2016, 17(1):651.

47. Zhang Y-N, Zhu X-Y, Fang L-P, He P, Wang Z-Q, Chen G, Sun L, Ye Z-F, Deng D-G, Li J-B: Identification and expression profiles of sex pheromone biosynthesis and transport related genes in Spodoptera litura. PloS one 2015, 10(10):e0140019. 
48. He P, Zhang Y-F, Hong D-Y, Wang J, Wang X-L, Zuo L-H, Tang X-F, Xu W-M, He M: A reference gene set for sex pheromone biosynthesis and degradation genes from the diamondback moth, Plutella xylostella, based on genome and transcriptome digital gene expression analyses. BMC genomics 2017, 18(1):219.

49. Antony B, Soffan A, Jakše J, Alfaifi S, Sutanto KD, Aldosari SA, Aldawood AS, Pain A: Genes involved in sex pheromone biosynthesis of Ephestia cautella, an important food storage pest, are determined by transcriptome sequencing. BMC genomics 2015, 16(1):532.

50. Gu S-H, Wu K-M, Guo Y-Y, Pickett JA, Field LM, Zhou J-J, Zhang Y-J: Identification of genes expressed in the sex pheromone gland of the black cutworm Agrotis ipsilon with putative roles in sex pheromone biosynthesis and transport. BMC genomics 2013, 14(1):636.

51. González-Caballero N, Valenzuela JG, Ribeiro JM, Cuervo P, Brazil RP: Transcriptome exploration of the sex pheromone gland of Lutzomyia longipalpis (Diptera: Psychodidae: Phlebotominae). Parasites \& vectors 2013, 6(1):56.

52. Vogel H, Heidel AJ, Heckel DG, Groot AT: Transcriptome analysis of the sex pheromone gland of the noctuid moth Heliothis virescens. BMC genomics 2010, 11(1):29.

53. Ding B-J, Löfstedt C: Analysis of the agrotis segetum pheromone gland transcriptome in the light of Sex pheromone biosynthesis. BMC genomics 2015, 16(1):711.

54. Zhou J-J, Field LM, He XL: Insect odorant-binding proteins: Do they offer an alternative pest control strategy? Outlooks on Pest Management 2010, 21(1):31-34.

55. Lee JM, Hull JJ, Kawai T, Goto C, Kurihara M, Tanokura M, Nagata K, Nagasawa H, Matsumoto S: Reevaluation of the PBAN receptor (PBANR) molecule: characterization of PBANR variants expressed in the pheromone glands of moths. Frontiers in endocrinology 2012, 3:6.

56. Nusawardani T, Kroemer J, Choi MY, Jurenka RA: Identification and characterization of the pyrokinin/pheromone biosynthesis activating neuropeptide family of $\mathrm{G}$ protein-coupled receptors from Ostrinia nubilalis. Insect molecular biology 2013, 22(3):331-340.

57. Kim Y-J, Nachman RJ, Aimanova K, Gill S, Adams ME: The pheromone biosynthesis activating neuropeptide (PBAN) receptor of Heliothis virescens: identification, functional expression, and structure-activity relationships of ligand analogs. Peptides 2008, 29(2):268-275.

58. Strandh M, Johansson T, Ahrén D, Löfstedt C: Transcriptional analysis of the pheromone gland of the turnip moth, Agrotis segetum (Noctuidae), reveals candidate genes involved in pheromone production. Insect molecular biology 2008, 17(1):73-85.

59. Koshihara T, Yamada H: Attractant activity of the female sex pheromone of diamondback moth, Plutella xylostella (L.), and analogue. Japanese Journal of Applied Entomology and Zoology 1980, 24(1):6-12.

60. Ohnishi A, Hashimoto K, Imai K, Matsumoto S: Functional characterization of the Bombyx mori fatty acid transport protein (BmFATP) within the silkmoth pheromone gland. Journal of Biological Chemistry 2009, 284(8):5128-5136. 
61. Qian S, Fujii T, Ito K, Nakano R, Ishikawa Y: Cloning and functional characterization of a fatty acid transport protein (FATP) from the pheromone gland of a lichen moth, Eilema japonica, which secretes an alkenyl sex pheromone. Insect biochemistry and molecular biology 2011, 41(1):22-28.

62. Hagström ÅK, Wang H-L, Liénard MA, Lassance J-M, Johansson T, Löfstedt C: A moth pheromone brewery: production of (Z)-11-hexadecenol by heterologous co-expression of two biosynthetic genes from a noctuid moth in a yeast cell factory. Microbial cell factories 2013, 12(1):125.

63. Fujii T, Suzuki MG, Katsuma S, Ito K, Rong Y, Matsumoto S, Ando T, Ishikawa Y: Discovery of a disused desaturase gene from the pheromone gland of the moth Ascotis selenaria, which secretes an epoxyalkenyl sex pheromone. Biochemical and biophysical research communications 2013, 441(4):849-855.

64. Antony B, Fujii T, Moto Ki, Matsumoto S, Fukuzawa M, Nakano R, Tatsuki S, Ishikawa Y: Pheromonegland-specific fatty-acyl reductase in the adzuki bean borer, Ostrinia scapulalis (Lepidoptera: Crambidae). Insect biochemistry and molecular biology 2009, 39(2):90-95.

65. Hagström ÅK, Liénard MA, Groot AT, Hedenström E, Löfstedt C: Semi-selective fatty acyl reductases from four heliothine moths influence the specific pheromone composition. PLOS One 2012, 7(5):e37230.

66. Lassance J-M, Groot AT, Liénard MA, Antony B, Borgwardt C, Andersson F, Hedenström E, Heckel DG, Löfstedt $C$ : Allelic variation in a fatty-acyl reductase gene causes divergence in moth sex pheromones. Nature 2010, 466(7305):486.

67. Liénard MA, Strandh M, Hedenström E, Johansson T, Löfstedt C: Key biosynthetic gene subfamily recruited for pheromone production prior to the extensive radiation of Lepidoptera. BMC evolutionary biology 2008, 8(1):270.

68. Bjostad L, Roelofs W: Sex pheromone biosynthesis in Trichoplusia ni: key steps involve delta-11 desaturation and chain-shortening. Science 1983, 220(4604):1387-1389.

69. Liénard MA, Löfsted C: Functional flexibility as a prelude to signal diversity? Role of a fatty acyl reductase in moth pheromone evolution: Role of a fatty acyl reductase in moth pheromone evolution. Communicative \& integrative biology 2010, 3(6):586-588.

70. Antony B, Ding B-J, Moto KI, Aldosari SA, Aldawood AS: Two fatty acyl reductases involved in moth pheromone biosynthesis. Scientific reports 2016, 6:29927.

71. MORSE D, MEIGHEN E: Pheromone biosynthesis: enzymatic studies in Lepidoptera. In: Pheromone biochemistry. Elsevier; 1987: 121-158.

72. Matsumoto S, Yoshiga T, Yokoyama N, Iwanaga M, Koshiba S, Kigawa T, Hirota H, Yokoyama S, Okano K, Mita K: Characterization of acyl-CoA-binding protein (ACBP) in the pheromone gland of the silkworm, Bombyx mori. Insect biochemistry and molecular biology 2001, 31(6-7):603-609.

73. Hu P, Gao C, Tao J, Lu P, Luo Y, Ren L: Sensilla on six olfactory organs of male Eogystia hippophaecolus (Lepidoptera: Cossidae). Microscopy Research and Technique 2018, 81(9):10591070. 
74. Ma PW, Roel ofs WL: Sex pheromone gland of the female European corn borer moth, Ostrinia nubilalis (Lepidoptera, Pyralidae): ultrastructural and biochemical evidences. Zoological science 2002, 19(5):501-511.

75. Scaloni A, Monti M, Angeli S, Pelosi P: Structural analysis and disulfide-bridge pairing of two odorantbinding proteins from Bombyx mori. Biochemical and biophysical research communications 1999, 266(2):386-391.

76. Hu P: Olfactory Gene Screening and Function Analysis of Pheromone Binding Proteins of Eogystia hippophaecolus(Lepidoptera: Cossidael. Beijing Forestry University 2017.

77. Zhang YN, Jin JY, Jin R, Xia YH, Zhou JJ, Deng JY, Dong SL: Differential expression patterns in chemosensory and non-chemosensory tissues of putative chemosensory genes identified by transcriptome analysis of insect pest the purple stem borer Sesamia inferens (Walker). PloS one 2013, 8(7):e69715.

78. Schooten Bv, Jiggins CD, Briscoe AD, Papa R: Genome-wide analysis of ionotropic receptors provides insight into their evolution in Heliconius butterflies. Bmc Genomics 2016, 17(1):1-15.

79. Benton R, Vannice KS, Gomez-Diaz C, Vosshall LB: Variant lonotropic Glutamate Receptors as Chemosensory Receptors in< i> Drosophila</i>. Cell 2009, 136(1):149-162.

80. Abuin L, Bargeton B, Ulbrich MH, Isacoff EY, Kellenberger S, Benton R: Functional architecture of olfactory ionotropic glutamate receptors. Neuron 2011, 69(1):44-60.

81. Jiang X, Pablo P, Ewald GW, Heinz B, Jürgen K: Identification and Characterization of Two "Sensory Neuron Membrane Proteins" (SNMPs) of the Desert Locust,Schistocerca gregaria(Orthoptera: Acrididae). Journal of Insect Science 2016, 16(1).

82. Vogt RG, Miller NE, Litvack R, Fandino RA, Sparks J, Staples J, Friedman R, Dickens JC: insect SNMP gene family. Insect Biochemistry \& Molecular Biology 2009, 39:448-456.

83. Rytz R, Croset V, Benton R: Ionotropic receptors (IRs): chemosensory ionotropic glutamate receptors in Drosophila and beyond. Insect biochemistry and molecular biology 2013, 43(9):888-897.

84. Koh T-W, He Z, Gorur-Shandilya S, Menuz K, Larter NK, Stewart S, Carlson JR: The Drosophila IR20a clade of ionotropic receptors are candidate taste and pheromone receptors. Neuron 2014, 83(4):850865.

85. Ai M, Min S, Grosjean Y, Leblanc C, Bell R, Benton R, Suh GS: Acid sensing by the Drosophila olfactory system. Nature 2010, 468(7324):691-695.

86. Grosjean Y, Rytz R, Farine J-P, Abuin L, Cortot J, Jefferis GS, Benton R: An olfactory receptor for foodderived odours promotes male courtship in Drosophila. Nature 2011, 478(7368):236-240.

87. Senthilan PR, Piepenbrock D, Ovezmyradov G, Nadrowski B, Bechstedt S, Pauls S, Winkler M, Möbius W, Howard J, Göpfert MC: Drosophila auditory organ genes and genetic hearing defects. Cel/ 2012, 150(5):1042-1054.

88. Finn R D CJ, Eddy S R. Finn RD, Clements J, Eddy SR. : HMMER web server: interactive sequence similarity searching. Nucleic Acids Res 39: W29-W37. Nucleic Acids Research 2011, 39(Web Server issue):29-37. 
89. Stefan Götz JMG, Terol J , et al.: High-throughput functional annotation and data mining with the Blast2GO suite. Nucleic Acids Research 2008, 36(10):3420-3435.

90. Mortazavi A, Williams BA, Mccue K, Schaeffer L, Wold B: Mapping and quantifying mammalian transcriptomes by RNA-Seq. Nature Methods 2008, 5(7):621-628.

91. Li B, Dewey CN: RSEM: accurate transcript quantification from RNA-Seq data with or without a reference genome. Bmc Bioinformatics 2011, 12(1):93-99.

92. Xia Y-H, Zhang Y-N, Hou X-Q, Li F, Dong S-L: Large number of putative chemoreception and pheromone biosynthesis genes revealed by analyzing transcriptome from ovipositor-pheromone glands of Chilo suppressalis. Scientific reports 2015, 5.

93. Durand N, Carot-Sans G, Bozzolan F, Rosell G, Siaussat D, Debernard S, Chertemps T, Maïbèche-Coisne $M$ : Degradation of pheromone and plant volatile components by a same odorant-degrading enzyme in the cotton leafworm, Spodoptera littoralis. PloS one 2011, 6(12):e29147.

94. Ishida Y, Leal WS: Rapid inactivation of a moth pheromone. Proceedings of the National Academy of Sciences 2005, 102(39):14075-14079.

95. Tamura K, Peterson D, Peterson N, Stecher G, Nei M, Kumar S: MEGA5: molecular evolutionary genetics analysis using maximum likelihood, evolutionary distance, and maximum parsimony methods. Molecular biology and evolution 2011, 28(10):2731-2739.

96. Saitou N, Nei M: The neighbor-joining method: a new method for reconstructing phylogenetic trees. Molecular biology and evolution 1987, 4(4):406-425.

\section{Tables}

Table 1 Functional annotation of unigenes using various public protein databases

\begin{tabular}{ccc}
\hline Database & Number & Percentage \\
\hline $\mathrm{Nr}$ & 18894 & $92.79 \%$ \\
Pfam & 12347 & $60.63 \%$ \\
Swissprot & 9190 & $45.13 \%$ \\
COG & 4557 & $22.38 \%$ \\
KOG & 11905 & $58.46 \%$ \\
GO & 10304 & $50.60 \%$ \\
KEGG & 8803 & $43.23 \%$ \\
\hline Total & 20363 & - \\
\hline
\end{tabular}

Table 2 Putative pheromone biosynthesis-related genes in the E. hippophaecolus pheromone gland 


\begin{tabular}{|c|c|c|c|c|c|c|c|}
\hline & & & & \multicolumn{4}{|c|}{ Best Blast Match } \\
\hline Number & Gene ID & $\begin{array}{l}\text { Gene } \\
\text { length } \\
\text { (bp) } \\
\end{array}$ & FPKM & Name & ACC. Number & Speceies & $\begin{array}{c}\text { E- } \\
\text { value }\end{array}$ \\
\hline \multicolumn{8}{|c|}{ Pheromone biosynthesis-activating neuropeptide } \\
\hline EhipPBAN1 & c35789.graph_c0 & 325 & 0.430 & $\begin{array}{l}\text { diapause hormone- } \\
\text { pheromone biosynthesis- } \\
\text { activating neuropeptide }\end{array}$ & AAL05596.1 & $\begin{array}{c}\text { Helicoverpa } \\
\text { armigera }\end{array}$ & $\begin{array}{l}2.00 \mathrm{E}- \\
38\end{array}$ \\
\hline EhipPBAN2 & c36253.graph_c0 & 290 & 0.482 & $\begin{array}{l}\text { diapause hormone- } \\
\text { pheromone biosynthesis } \\
\text { activating neuropeptide }\end{array}$ & AOY34021.1 & $\begin{array}{l}\text { Ostrinia } \\
\text { nubilalis }\end{array}$ & $\begin{array}{c}1.00 \mathrm{E}- \\
40\end{array}$ \\
\hline \multicolumn{8}{|c|}{ Pheromone biosynthesis-activating neuropeptide receptor } \\
\hline EhipPBANr-1 & c4439.graph_c0 & 1516 & 0.676 & $\begin{array}{l}\text { pheromone biosynthesis- } \\
\text { activating neuropeptide } \\
\text { receptor subtype C }\end{array}$ & ACQ90221.1 & $\begin{array}{l}\text { Manduca } \\
\text { sexta }\end{array}$ & 0 \\
\hline EhipPBANr-2 & c30664.graph_c0 & 321 & 0.726 & $\begin{array}{l}\text { pheromone biosynthesis- } \\
\text { activating neuropeptide } \\
\text { receptor isoform B }\end{array}$ & ABU93813.1 & $\begin{array}{l}\text { Heliothis } \\
\text { virescens }\end{array}$ & $\begin{array}{c}\text { 7.00E- } \\
11\end{array}$ \\
\hline \multicolumn{8}{|c|}{ Acetyl-CoA carboxylase } \\
\hline EhipACC1 & c48404.graph_c0 & 622 & 0.300 & acetyl-CoA carboxylase 1 & NP_001009256.1 & Ovis aries & $\begin{array}{c}4.00 \mathrm{E}- \\
137\end{array}$ \\
\hline EhipACC2 & c25021.graph_c0 & 7711 & 21.823 & acetyl-CoA carboxylase & ALS92678.1 & $\begin{array}{c}\text { Helicoverpa } \\
\text { armigera }\end{array}$ & 0 \\
\hline EhipACC3 & c38636.graph_c0 & 420 & 0.644 & $\begin{array}{l}\text { acetyl coenzyme A } \\
\text { carboxylase alpha }\end{array}$ & ABC96905.1 & Capra hircus & $\begin{array}{c}7.00 \mathrm{E}- \\
81\end{array}$ \\
\hline EhipACC4 & c35767.graph_c0 & 443 & 0.526 & acetyl-CoA carboxylase 1 & NP_001009256.1 & Ovis aries & $\begin{array}{c}4.00 \mathrm{E}- \\
97\end{array}$ \\
\hline EhipAcc5 & c37234.graph_c0 & 316 & 0.442 & acetyl-CoA carboxylase 1 & XP_020740818.1 & $\begin{array}{l}\text { Odocoileus } \\
\text { virginianus }\end{array}$ & $\begin{array}{c}1.00 \mathrm{E}- \\
68\end{array}$ \\
\hline \multicolumn{8}{|c|}{ Fatty acid synthase } \\
\hline EhipFAS1 & c35372.graph_c0 & 647 & 0.432 & Fatty acid synthase & KPJ07769.1 & $\begin{array}{l}\text { Papilio } \\
\text { machaon }\end{array}$ & $\begin{array}{c}2.00 \mathrm{E}- \\
81\end{array}$ \\
\hline EhipFAS2 & c36413.graph_c0 & 227 & 0.000 & $\begin{array}{l}\text { fatty acid synthase, isoform } \\
\text { CRA_a }\end{array}$ & EDL34808.1 & $\begin{array}{c}\text { Mus } \\
\text { musculus }\end{array}$ & $\begin{array}{c}4.00 \mathrm{E}- \\
43\end{array}$ \\
\hline EhipFAS3 & c24943.graph_c1 & 6032 & 913.479 & fatty acid synthase & AGR49310.1 & $\begin{array}{l}\text { Agrotis } \\
\text { ipsilon }\end{array}$ & 0 \\
\hline EhipFAS4 & c10701.graph_c0 & 1171 & 0.876 & $\begin{array}{l}\text { PREDICTED: fatty acid } \\
\text { synthase-like }\end{array}$ & XP_013134398.1 & $\begin{array}{l}\text { Papilio } \\
\text { polytes }\end{array}$ & $\begin{array}{c}6.00 \mathrm{E}- \\
114\end{array}$ \\
\hline EhipFAS5 & c39724.graph_c0 & 522 & 0.536 & fatty acid synthase & NP_001272558.1 & Capra hircus & $\begin{array}{c}6.00 \mathrm{E}- \\
85\end{array}$ \\
\hline EhipFAS6 & c27600.graph_c0 & 1074 & 0.694 & fatty acid synthase & ABB36643.1 & Capra hircus & 0 \\
\hline \multicolumn{8}{|c|}{ Acyl-CoA desaturase } \\
\hline EhipDES1 & c38302.graph_c0 & 215 & 0.000 & Acyl-CoA desaturase 1 & KPI92671.1 & $\begin{array}{l}\text { Papilio } \\
\text { xuthus }\end{array}$ & $\begin{array}{c}2.00 \mathrm{E}- \\
34\end{array}$ \\
\hline $\begin{array}{c}\text { Ehip } \Delta 11 \text { Des- } \\
1\end{array}$ & c31444.graph_c0 & 1028 & 0.499 & $\begin{array}{l}\text { acyl-CoA Delta(11) } \\
\text { desaturase-like }\end{array}$ & NP_001296508.1 & $\begin{array}{c}\text { Bombyx } \\
\text { mori }\end{array}$ & 0 \\
\hline EhipDES2 & c44591.graph_c0 & 890 & 0.262 & desaturase & AIM40222.1 & $\begin{array}{c}\text { Cydia } \\
\text { pomonella }\end{array}$ & 0 \\
\hline $\begin{array}{l}\text { Ehip } \triangle 11 \text { DES- } \\
\text { 4(DES3) }\end{array}$ & c5434.graph_c1 & 547 & 7.924 & desaturase & AIM40219.1 & $\begin{array}{c}\text { Cydia } \\
\text { pomonella }\end{array}$ & $\begin{array}{c}4.00 \mathrm{E}- \\
85\end{array}$ \\
\hline EhipDES4 & c20775.graph_c0 & 3494 & 2.291 & desaturase & AAQ74260.1 & $\begin{array}{l}\text { Spodoptera } \\
\text { littoralis }\end{array}$ & 0 \\
\hline EhipDES5 & c13452.graph_c0 & 1270 & 41.303 & desaturase & ARD71185.1 & $\begin{array}{l}\text { Spodoptera } \\
\text { exigua }\end{array}$ & $\begin{array}{c}4.00 \mathrm{E}- \\
173\end{array}$ \\
\hline EhipDES6 & c13089.graph_c0 & 1447 & 1.407 & Acyl-CoA desaturase & KPI99990.1 & $\begin{array}{l}\text { Papilio } \\
\text { xuthus }\end{array}$ & 0 \\
\hline Ehip $\triangle 4$ DES & c21169.graph_c0 & 1728 & 1.910 & $\begin{array}{l}\text { Sphingolipid delta(4)- } \\
\text { desaturase DES1 }\end{array}$ & JAA80499.1 & $\begin{array}{l}\text { Pararge } \\
\text { aegeria }\end{array}$ & 0 \\
\hline Ehip $\Delta 9$ DES-1 & c19932.graph_c1 & 1167 & 379.279 & acyl-CoA delta-9 desaturase & AAK94070.1 & Epiphyas & $2.00 \mathrm{E}-$ \\
\hline
\end{tabular}




\begin{tabular}{|c|c|c|c|c|c|c|c|}
\hline & & & & & & postvittana & 43 \\
\hline Ehip $\Delta 9 \mathrm{DES}-2$ & c24745.graph_c1 & 5899 & 604.395 & $\begin{array}{l}\text { acyl-CoA-delta9-3a- } \\
\text { desaturase }\end{array}$ & ABX71810.1 & $\begin{array}{l}\text { Dendrolimus } \\
\text { punctatus }\end{array}$ & 0 \\
\hline $\begin{array}{c}\text { Ehip } \Delta 11 \text { DES- } \\
2\end{array}$ & c5434.graph_c0 & 608 & 10.502 & $\begin{array}{c}\text { PREDICTED: acyl-CoA } \\
\text { Delta(11) desaturase-like }\end{array}$ & XP_013195132.1 & $\begin{array}{l}\text { Amyelois } \\
\text { transitella }\end{array}$ & $\begin{array}{c}1.00 \mathrm{E}- \\
117\end{array}$ \\
\hline Ehip $\Delta 9$ DES-3 & c19932.graph_c2 & 1299 & 489.669 & acyl-CoA delta-9 desaturase & AAF81790.2 & $\begin{array}{c}\text { Helicoverpa } \\
\text { zea }\end{array}$ & $\begin{array}{c}3.00 \mathrm{E}- \\
166\end{array}$ \\
\hline EhipDES7 & c5280.graph_c0 & 5138 & 1.660 & acyl-CoA desaturase & NP_001272548.1 & Capra hircus & 0 \\
\hline $\begin{array}{c}\text { Ehip } \Delta 11 \text { DES- } \\
3\end{array}$ & c20663.graph_c0 & 2368 & 346.889 & $\begin{array}{l}\text { PREDICTED: acyl-CoA } \\
\text { Delta(11) desaturase }\end{array}$ & XP_008550563.1 & $\begin{array}{l}\text { Microplitis } \\
\text { demolitor }\end{array}$ & $\begin{array}{c}5.00 \mathrm{E}- \\
109\end{array}$ \\
\hline EhipDES8 & c51235.graph_c0 & 307 & 0.304 & $\begin{array}{l}\text { PREDICTED: fatty acid } \\
\text { desaturase } 2\end{array}$ & XP_018892033.1 & $\begin{array}{l}\text { Gorilla } \\
\text { gorilla }\end{array}$ & $\begin{array}{c}1.00 \mathrm{E}- \\
54\end{array}$ \\
\hline EhipDES9 & c24941.graph_c5 & 1877 & 37.385 & desaturase & ARD71180.1 & $\begin{array}{l}\text { Spodoptera } \\
\text { exigua }\end{array}$ & 0 \\
\hline \multicolumn{8}{|c|}{ Fatty Acyl Reductase } \\
\hline EhipFAR1 & c23161.graph_c0 & 2228 & 13.602 & Fatty Acyl Reductase-3 & JAV01988.1 & $\begin{array}{c}\text { Plutella } \\
\text { xylostella }\end{array}$ & $\begin{array}{l}1.00 \mathrm{E}- \\
99\end{array}$ \\
\hline EhipFAR2 & c22156.graph_c0 & 2008 & 1780.060 & fatty-acyl-CoA reductase & AGD98718.1 & $\begin{array}{l}\text { Bicyclus } \\
\text { anynana }\end{array}$ & $\begin{array}{c}3.00 \mathrm{E}- \\
143\end{array}$ \\
\hline EhipFAR3 & c20658.graph_c0 & 3456 & 1.767 & fatty acyl-CoA reductase 12 & AKD01790.1 & $\begin{array}{c}\text { [Helicoverpa } \\
\text { assulta }\end{array}$ & 0 \\
\hline EhipFAR4 & c10341.graph_c0 & 1284 & 1.016 & fatty acyl reductase & ARD71198.1 & $\begin{array}{l}\text { Spodoptera } \\
\text { exigua }\end{array}$ & 0 \\
\hline EhipFAR5 & c11193.graph_c0 & 1132 & 1.276 & fatty-acyl CoA reductase II & ADD62442.1 & $\begin{array}{l}\text { Yponomeuta } \\
\text { padellus }\end{array}$ & $\begin{array}{c}1.00 \mathrm{E}- \\
98\end{array}$ \\
\hline EhipFAR6 & c24306.graph_c2 & 1165 & 35.305 & fatty-acyl CoA reductase 6 & EHJ76493.1 & $\begin{array}{l}\text { Danaus } \\
\text { plexippus }\end{array}$ & $\begin{array}{c}9.00 \mathrm{E}- \\
58\end{array}$ \\
\hline EhipFAR7 & c18110.graph_c0 & 1788 & 2.020 & fatty acyl-CoA reductase 7 & AKD01785.1 & $\begin{array}{c}\text { Helicoverpa } \\
\text { assulta }\end{array}$ & 0 \\
\hline EhipFAR8 & c23034.graph_c0 & 2269 & 7.189 & fatty acyl reductase & ARD71186.1 & $\begin{array}{l}\text { Spodoptera } \\
\text { exigua }\end{array}$ & 0 \\
\hline EhipFAR9 & c24306.graph_c1 & 1229 & 38.766 & fatty acyl-CoA reductase 4 & AKD01782.1 & $\begin{array}{c}\text { Helicoverpa } \\
\text { assulta }\end{array}$ & $\begin{array}{c}1.00 \mathrm{E}- \\
158\end{array}$ \\
\hline EhipFAR10 & c24663.graph_c0 & 7583 & 72.966 & fatty acyl-CoA reductase 13 & AKD01774.1 & $\begin{array}{l}\text { Helicoverpa } \\
\text { armigera }\end{array}$ & 0 \\
\hline EhipFAR11 & c23247.graph_c1 & 1769 & 14.438 & fatty-acyl CoA reductase 3 & ADI82776.1 & $\begin{array}{l}\text { Ostrinia } \\
\text { nubilalis }\end{array}$ & 0 \\
\hline EhipFAR12 & c9329.graph_c0 & 228 & 0.204 & fatty acyl-CoA reductase 1 & NP_001180219.1 & $\begin{array}{c}\text { Apis } \\
\text { mellifera }\end{array}$ & $\begin{array}{c}4.00 \mathrm{E}- \\
14\end{array}$ \\
\hline EhipFAR13 & c22039.graph_c0 & 1284 & 4.813 & fatty acyl-CoA reductase 1 & NP_001299710.1 & $\begin{array}{l}\text { Papilio } \\
\text { xuthus }\end{array}$ & 0 \\
\hline EhipFAR14 & c30760.graph_c0 & 469 & 0.497 & fatty acyl-CoA reductase 10 & AKD01788.1 & $\begin{array}{l}\text { [Helicoverpa } \\
\text { assulta }\end{array}$ & $\begin{array}{c}2.00 \mathrm{E}- \\
58\end{array}$ \\
\hline EhipFAR15 & c15554.graph_c0 & 510 & 1.188 & fatty acyl-CoA reductase 6 & AKD01767.1 & $\begin{array}{c}\text { Helicoverpa } \\
\text { armigera }\end{array}$ & $\begin{array}{c}1.00 \mathrm{E}- \\
10\end{array}$ \\
\hline EhipFAR16 & c24624.graph_c1 & 1091 & 7.958 & fatty-acyl CoA reductase 1 & ADI82774.1 & $\begin{array}{c}\text { Ostrinia } \\
\text { nubilalis }\end{array}$ & $\begin{array}{c}9.00 \mathrm{E}- \\
143\end{array}$ \\
\hline EhipFAR17 & c9053.graph_c0 & 1816 & 74.181 & $\begin{array}{l}\text { PREDICTED: very-long-chain } \\
\text { enoyl-CoA reductase }\end{array}$ & XP_013134963.1 & $\begin{array}{l}\text { Papilio } \\
\text { polytes }\end{array}$ & $\begin{array}{c}9.00 \mathrm{E}- \\
175\end{array}$ \\
\hline EhipFAR18 & c26609.graph_c0 & 822 & 0.680 & fatty acyl reductase & ARD71192.1 & $\begin{array}{l}\text { Spodoptera } \\
\text { exigua }\end{array}$ & $\begin{array}{c}5.00 \mathrm{E}- \\
144\end{array}$ \\
\hline EhipFAR19 & c24937.graph_c1 & 2074 & 18.488 & fatty acid reductase & AFD04727.1 & $\begin{array}{c}\text { Helicoverpa } \\
\text { assulta] }\end{array}$ & $\begin{array}{c}8.00 \mathrm{E}- \\
152\end{array}$ \\
\hline \multicolumn{8}{|c|}{ Aldo-keto/Aldehyde Reductase } \\
\hline EhipREDald1 & c22250.graph_c0 & 1476 & 33.439 & $\begin{array}{l}\text { PREDICTED: aldo-keto } \\
\text { reductase AKR2E4 }\end{array}$ & XP_004928930.1 & $\begin{array}{c}\text { Bombyx } \\
\text { mori }\end{array}$ & $\begin{array}{c}1.00 \mathrm{E}- \\
175\end{array}$ \\
\hline EhipREDald2 & c19531.graph_c0 & 1194 & 5.894 & $\begin{array}{l}\text { PREDICTED: aldo-keto } \\
\text { reductase AKR2E4-like }\end{array}$ & XP_013143141.1 & $\begin{array}{l}\text { Papilio } \\
\text { polytes }\end{array}$ & $\begin{array}{c}2.00 \mathrm{E}- \\
172\end{array}$ \\
\hline EhipREDald3 & c13706.graph_c0 & 1220 & 28.040 & Aldehyde reductase-12 & JAV02109.1 & Plutella & $1.00 \mathrm{E}-$ \\
\hline
\end{tabular}




\begin{tabular}{|c|c|c|c|c|c|c|c|}
\hline & & & & & & xylostella & 163 \\
\hline EhipREDald4 & c21883.graph_c0 & 1050 & 5.086 & $\begin{array}{l}\text { PREDICTED: aldo-keto } \\
\text { reductase AKR2E4-like }\end{array}$ & XP_014367612.1 & $\begin{array}{l}\text { Papilio } \\
\text { machaon }\end{array}$ & $\begin{array}{c}2.00 \mathrm{E}- \\
147\end{array}$ \\
\hline EhipREDald5 & c14137.graph_c0 & 1189 & 28.497 & $\begin{array}{l}\text { PREDICTED: aldose } \\
\text { reductase-like isoform } \times 1\end{array}$ & XP_013174473.1 & $\begin{array}{l}\text { Papilio } \\
\text { xuthus }\end{array}$ & 0 \\
\hline EhipREDald6 & c15484.graph_c0 & 1087 & 2.015 & $\begin{array}{l}\text { PREDICTED: aldose } \\
\text { reductase-like }\end{array}$ & XP_013174394.1 & $\begin{array}{l}\text { Papilio } \\
\text { xuthus }\end{array}$ & $\begin{array}{c}2.00 \mathrm{E}- \\
169\end{array}$ \\
\hline EhipREDald7 & c24729.graph_c1 & 1455 & 24.347 & $\begin{array}{l}\text { PREDICTED: aldo-keto } \\
\text { reductase AKR2E4-like } \\
\text { isoform X1 }\end{array}$ & XP_004933321.1 & $\begin{array}{l}\text { Bombyx } \\
\text { mori }\end{array}$ & 0 \\
\hline \multicolumn{8}{|c|}{ Acetyl-CoA acetyltransferase } \\
\hline EhipACT-1 & c38955.graph_c0 & 316 & 0.442463 & $\begin{array}{l}\text { acetyl-CoA acetyltransferase, } \\
\text { mitochondrial isoform X4 }\end{array}$ & XP_020747028.1 & $\begin{array}{l}\text { Odocoileus } \\
\text { virginianus }\end{array}$ & $\begin{array}{c}2.00 \mathrm{E}- \\
41\end{array}$ \\
\hline EhipACT-2 & c21157.graph_c0 & 2428 & 2.207457 & $\begin{array}{c}\text { PREDICTED: N-alpha- } \\
\text { acetyltransferase } 60 \text { isoform } \\
\text { X2 }\end{array}$ & XP_011555279.1 & $\begin{array}{l}\text { Plutella } \\
\text { xylostella }\end{array}$ & $\begin{array}{c}2.00 \mathrm{E}- \\
165\end{array}$ \\
\hline EhipACT-3 & c31920.graph_c0 & 966 & 0.627205 & $\begin{array}{c}\text { acetyl-CoA acetyltransferase, } \\
\text { mitochondrial precursor }\end{array}$ & NP_001039540.1 & Bos taurus & 0 \\
\hline EhipACT-4 & c23246.graph_c0 & 2892 & 143.1221 & acetyltransferase 1 & BAH03386.1 & $\begin{array}{l}\text { Ostrinia } \\
\text { scapulalis }\end{array}$ & 0 \\
\hline EhipACT-5 & c13199.graph_c0 & 1822 & 41.52283 & $\begin{array}{l}\text { fatty alcohol } \\
\text { acetyltransferase }\end{array}$ & AIN34682.1 & $\begin{array}{l}\text { Agrotis } \\
\text { segetum }\end{array}$ & 0 \\
\hline EhipACT-6 & c23052.graph_c0 & 2375 & 10.53757 & $\begin{array}{c}\mathrm{N} \text {-alpha-acetyltransferase } 35 \\
\text { NatC auxiliary subunit }\end{array}$ & KPI97545.1 & $\begin{array}{l}\text { Papilio } \\
\text { xuthus }\end{array}$ & 0 \\
\hline EhipACT-7 & c22060.graph_c0 & 2381 & 23.11712 & $\begin{array}{c}\text { fatty alcohol } \\
\text { acetyltransferase }\end{array}$ & AIN34708.1 & $\begin{array}{l}\text { Agrotis } \\
\text { segetum }\end{array}$ & 0 \\
\hline EhipACT-8 & c18248.graph_c0 & 1477 & 7.964045 & $\begin{array}{c}\mathrm{N} \text {-acetyltransferase } 9 \text {-like } \\
\text { protein }\end{array}$ & KOB74382.1 & $\begin{array}{c}\text { Operophtera } \\
\text { brumata }\end{array}$ & $\begin{array}{c}3.00 \mathrm{E}- \\
44\end{array}$ \\
\hline EhipACT-9 & c18773.graph_c0 & 1699 & 32.09487 & $\mathrm{~N}$-acetyltransferase & JAA88866.1 & $\begin{array}{l}\text { Pararge } \\
\text { aegeria }\end{array}$ & $\begin{array}{c}5.00 \mathrm{E}- \\
118\end{array}$ \\
\hline EhipACT-10 & c9805.graph_c0 & 1465 & 0.731701 & $\mathrm{~N}$-acetyltransferase ESCO2 & KPJ00801.1 & $\begin{array}{l}\text { Papilio } \\
\text { xuthus }\end{array}$ & $\begin{array}{c}2.00 \mathrm{E}- \\
142\end{array}$ \\
\hline EhipACT-11 & c16633.graph_c0 & 1044 & 67.61795 & $\begin{array}{c}\mathrm{N} \text {-alpha-acetyltransferase } 10, \\
\text { NatA catalytic subunit }\end{array}$ & KPJ07254.1 & $\begin{array}{l}\text { Papilio } \\
\text { machaon }\end{array}$ & $\begin{array}{c}5.00 \mathrm{E}- \\
124\end{array}$ \\
\hline EhipACT-12 & c17165.graph_c0 & 1570 & 37.04743 & $\begin{array}{c}\text { N-terminal acetyltransferase } \\
\text { C complex catalytic subunit } \\
\text { Mak3 }\end{array}$ & JAA88748.1 & $\begin{array}{l}\text { Pararge } \\
\text { aegeria }\end{array}$ & $\begin{array}{l}9.00 \mathrm{E}- \\
98\end{array}$ \\
\hline EhipACT-13 & c17529.graph_c0 & 1466 & 10.62102 & $\mathrm{~N}$-acetyltransferase & EHJ68864.1 & $\begin{array}{l}\text { Danaus } \\
\text { plexippus }\end{array}$ & $\begin{array}{c}5.00 \mathrm{E}- \\
116\end{array}$ \\
\hline \multicolumn{8}{|c|}{ Fatty acid transport protein } \\
\hline EhipFATP-1 & c22320.graph_c0 & 3673 & 30.875 & $\begin{array}{l}\text { PREDICTED: long-chain fatty } \\
\text { acid transport protein 4-like }\end{array}$ & XP_013181373.1 & $\begin{array}{l}\text { Papilio } \\
\text { xuthus }\end{array}$ & 0 \\
\hline \multicolumn{8}{|c|}{ Acyl-CoA binding protein } \\
\hline EhipACBP-1 & c16365.graph_c0 & 650 & 4.374 & acyl-CoA binding protein-like & NP_001037023.1 & $\begin{array}{c}\text { Bombyx } \\
\text { mori }\end{array}$ & $\begin{array}{c}4.00 \mathrm{E}- \\
42\end{array}$ \\
\hline \multicolumn{8}{|c|}{ Elongation of very long chain fatty acids protein } \\
\hline EhipELO1 & c24384.graph_c0 & 4363 & 81.521 & $\begin{array}{l}\text { elongation of very long chain } \\
\text { fatty acids protein } \\
\text { AAEL008004-like }\end{array}$ & XP_022816647.1 & $\begin{array}{l}\text { Spodoptera } \\
\quad \text { litura }\end{array}$ & 0 \\
\hline EhipELO2 & c8605.graph_c0 & 1393 & 100.874 & $\begin{array}{l}\text { elongation of very long chain } \\
\text { fatty acids protein } \\
\text { AAEL008004-like }\end{array}$ & XP_022831965.1 & $\begin{array}{l}\text { Spodoptera } \\
\quad \text { litura }\end{array}$ & $\begin{array}{c}4.00 \mathrm{E}- \\
139\end{array}$ \\
\hline EhipELO3 & c25020.graph_c0 & 5370 & 30.610 & $\begin{array}{l}\text { elongation of very long chain } \\
\text { fatty acids protein } \\
\text { AAEL008004-like }\end{array}$ & XP_026485844.1 & $\begin{array}{l}\text { Vanessa } \\
\text { tameamea }\end{array}$ & $\begin{array}{c}5.00 \mathrm{E}- \\
176\end{array}$ \\
\hline EhipELO4 & c23160.graph_c0 & 3422 & 16.544 & $\begin{array}{l}\text { elongation of very long chain } \\
\text { fatty acids protein 7-like }\end{array}$ & XP_021181973.1 & $\begin{array}{c}\text { Helicoverpa } \\
\text { armigera }\end{array}$ & 0 \\
\hline EhipEL05 & c23606.graph_c1 & 2514 & 8.167 & $\begin{array}{l}\text { elongation of very long chain } \\
\text { fatty acids protein } 6\end{array}$ & XP_026490072.1 & $\begin{array}{l}\text { Vanessa } \\
\text { tameamea }\end{array}$ & 0 \\
\hline
\end{tabular}


Table 3 Unigenes related to chemoreception in the E. hippophaecolus pheromone gland 


\begin{tabular}{|c|c|c|c|c|c|c|c|c|}
\hline \multirow[b]{2}{*}{ Number } & \multirow[b]{2}{*}{ Gene ID } & \multirow[b]{2}{*}{$\begin{array}{l}\text { Gene } \\
\text { length(bp) }\end{array}$} & \multirow[b]{2}{*}{$\begin{array}{c}\text { ORF } \\
\text { length(bp) }\end{array}$} & \multirow[b]{2}{*}{ FPKM } & \multicolumn{4}{|c|}{ Best Blast Match } \\
\hline & & & & & Name & ACC. Number & Speceies & $\begin{array}{c}\text { E- } \\
\text { value }\end{array}$ \\
\hline \multicolumn{9}{|c|}{ Odorant Binding Protein } \\
\hline EhipOBP4 & c25562.graph_c0 & 845 & 408 & 1.489 & $\begin{array}{l}\text { Odorant } \\
\text { Binding } \\
\text { Protein4 }\end{array}$ & AOG12857.1 & $\begin{array}{c}\text { Eogystia } \\
\text { hippophaecolus }\end{array}$ & $\begin{array}{c}1.00 \mathrm{E}- \\
71\end{array}$ \\
\hline EhipOBP13 & c10691.graph_c0 & 999 & 687 & 3.440 & $\begin{array}{c}\text { Odorant } \\
\text { Binding } \\
\text { Protein13 }\end{array}$ & AOG12868.1 & $\begin{array}{c}\text { Eogystia } \\
\text { hippophaecolus }\end{array}$ & $\begin{array}{c}1.00 \mathrm{E}- \\
77\end{array}$ \\
\hline EhipOBP2 & c18249.graph_c0 & 893 & 726 & 29.905 & $\begin{array}{l}\text { Odorant } \\
\text { Binding } \\
\text { Protein2 }\end{array}$ & AOG12855.1 & $\begin{array}{c}\text { Eogystia } \\
\text { hippophaecolus }\end{array}$ & $\begin{array}{c}5.00 \mathrm{E}- \\
163\end{array}$ \\
\hline EhipOBP25 & c28284.graph_c0 & 719 & 453 & 0.778 & $\begin{array}{l}\text { odorant } \\
\text { binding } \\
\text { protein } 6\end{array}$ & ALZ45421.1 & $\begin{array}{l}\text { Athetis } \\
\text { dissimilis }\end{array}$ & $\begin{array}{c}8.00 \mathrm{E}- \\
47\end{array}$ \\
\hline EhipOBP17 & c8485.graph_c0 & 717 & 450 & 2648.035 & $\begin{array}{l}\text { Odorant } \\
\text { Binding } \\
\text { Protein17 }\end{array}$ & AOG12872.1 & $\begin{array}{c}\text { Eogystia } \\
\text { hippophaecolus }\end{array}$ & $\begin{array}{c}5.00 \mathrm{E}- \\
83\end{array}$ \\
\hline EhipOBP1 & c14548.graph_c0 & 655 & 504 & 0.854 & $\begin{array}{l}\text { Odorant } \\
\text { Binding } \\
\text { Protein1 }\end{array}$ & AOG12859.1 & $\begin{array}{c}\text { Eogystia } \\
\text { hippophaecolus }\end{array}$ & $\begin{array}{c}5.00 \mathrm{E}- \\
104\end{array}$ \\
\hline EhipOBP9 & c14205.graph_c0 & 1051 & 402 & 138.399 & $\begin{array}{l}\text { Odorant } \\
\text { Binding } \\
\text { Protein9 }\end{array}$ & AOG12864.1 & $\begin{array}{c}\text { Eogystia } \\
\text { hippophaecolus }\end{array}$ & $\begin{array}{c}2.00 \mathrm{E}- \\
89\end{array}$ \\
\hline EhipGOBP2 & c31476.graph_c0 & 599 & 438 & 0.622 & $\begin{array}{c}\text { Genral } \\
\text { Odorant } \\
\text { Binding } \\
\text { Protein2 }\end{array}$ & AOG12862.1 & $\begin{array}{c}\text { Eogystia } \\
\text { hippophaecolus }\end{array}$ & $\begin{array}{c}7.00 \mathrm{E}- \\
117\end{array}$ \\
\hline EhipOBP24 & c13721.graph_c0 & 742 & 414 & 10.929 & $\begin{array}{l}\text { Odorant } \\
\text { Binding } \\
\text { Protein24 }\end{array}$ & AOG12879.1 & $\begin{array}{c}\text { Eogystia } \\
\text { hippophaecolus }\end{array}$ & $\begin{array}{c}4.00 \mathrm{E}- \\
93\end{array}$ \\
\hline EhipOBP19 & c26667.graph_c0 & 618 & 471 & 1.207 & $\begin{array}{l}\text { Odorant } \\
\text { Binding } \\
\text { Protein19 }\end{array}$ & AOG12874.1 & $\begin{array}{c}\text { Eogystia } \\
\text { hippophaecolus }\end{array}$ & $\begin{array}{c}1.00 \mathrm{E}- \\
102\end{array}$ \\
\hline EhipOBP26 & c8565.graph_c0 & 746 & 576 & 63.787 & $\begin{array}{l}\text { Odorant } \\
\text { Binding } \\
\text { Protein }\end{array}$ & JAl18067.1 & $\begin{array}{l}\text { Epiphyas } \\
\text { postvittana }\end{array}$ & $\begin{array}{c}2.00 \mathrm{E}- \\
86\end{array}$ \\
\hline EhipOBP23 & c27601.graph_c0 & 274 & 213 & 0.680 & $\begin{array}{c}\text { Odorant } \\
\text { Binding } \\
\text { Protein23 }\end{array}$ & AOG12878.1 & $\begin{array}{c}\text { Eogystia } \\
\text { hippophaecolus }\end{array}$ & $\begin{array}{c}7.00 \mathrm{E}- \\
60\end{array}$ \\
\hline EhipOBP8 & c1156.graph_c0 & 234 & 150 & 0.797 & $\begin{array}{l}\text { Odorant } \\
\text { Binding } \\
\text { Protein8 }\end{array}$ & AOG12863.1 & $\begin{array}{c}\text { Eogystia } \\
\text { hippophaecolus }\end{array}$ & $\begin{array}{c}6.00 \mathrm{E}- \\
20\end{array}$ \\
\hline EhipPBP3 & c6172.graph_c0 & 652 & 507 & 0.572 & $\begin{array}{c}\text { Pheromone } \\
\text { binding } \\
\text { protein } 3\end{array}$ & AOG12882.1 & $\begin{array}{c}\text { Eogystia } \\
\text { hippophaecolus }\end{array}$ & $\begin{array}{c}6.00 \mathrm{E}- \\
112\end{array}$ \\
\hline EhipOBP7 & c43627.graph_c0 & 202 & 147 & 0.461 & $\begin{array}{l}\text { Odorant } \\
\text { Binding } \\
\text { Protein7 }\end{array}$ & AOG 12861.1 & $\begin{array}{c}\text { Eogystia } \\
\text { hippophaecolus }\end{array}$ & $\begin{array}{c}1.00 \mathrm{E}- \\
33\end{array}$ \\
\hline EhipOBP27 & c43512.graph_c0 & 323 & 141 & 0.289 & $\begin{array}{l}\text { odorant- } \\
\text { binding } \\
\text { protein } 14\end{array}$ & ALS03862.1 & $\begin{array}{l}\text { Ectropis } \\
\text { obliqua }\end{array}$ & $\begin{array}{c}2.00 \mathrm{E}- \\
30\end{array}$ \\
\hline \multicolumn{9}{|c|}{ Chemosensory protein } \\
\hline EhipCSP4 & c25191.graph_c0 & 461 & 369 & 504.782 & $\begin{array}{c}\text { chemosensory } \\
\text { protein } 4\end{array}$ & AOG12888.1 & $\begin{array}{c}\text { Eogystia } \\
\text { hippophaecolus }\end{array}$ & $\begin{array}{c}5.00 \mathrm{E}- \\
84\end{array}$ \\
\hline EhipCSP15 & c32820.graph_c0 & 571 & 321 & 0.163 & $\begin{array}{c}\text { chemosensory } \\
\text { protein } 15\end{array}$ & AOG12899.1 & & $\begin{array}{c}1.00 \mathrm{E}- \\
71\end{array}$ \\
\hline EhipCSP19 & c15890.graph_c1 & 608 & 363 & 283.623 & chemosensory & BAV56810.1 & Ostrinia & 4.00E- \\
\hline
\end{tabular}




\begin{tabular}{|c|c|c|c|c|c|c|c|c|}
\hline & & & & & protein 6 & & furnacalis & 56 \\
\hline EhipCSP14 & c5502.graph_c1 & 623 & 396 & 165.328 & $\begin{array}{c}\text { chemosensory } \\
\text { protein } 14\end{array}$ & AOG12898.1 & $\begin{array}{c}\text { Eogystia } \\
\text { hippophaecolus }\end{array}$ & $\begin{array}{c}1.00 \mathrm{E}- \\
86\end{array}$ \\
\hline EhipCSP3 & c8449.graph_c0 & 570 & 372 & 124.365 & $\begin{array}{c}\text { chemosensory } \\
\text { protein3 }\end{array}$ & AOG12887.1 & $\begin{array}{c}\text { Eogystia } \\
\text { hippophaecolus }\end{array}$ & $\begin{array}{c}2.00 \mathrm{E}- \\
85\end{array}$ \\
\hline EhipCSP11 & c32257.graph_c0 & 224 & 153 & 0.624 & $\begin{array}{c}\text { chemosensory } \\
\text { protein } 11\end{array}$ & AOG12895.1 & $\begin{array}{c}\text { Eogystia } \\
\text { hippophaecolus }\end{array}$ & $\begin{array}{c}2.00 \mathrm{E}- \\
48\end{array}$ \\
\hline EhipCSP8 & c5518.graph_c0 & 656 & 387 & 1225.543 & $\begin{array}{c}\text { chemosensory } \\
\text { protein8 }\end{array}$ & AOG12892.1 & $\begin{array}{c}\text { Eogystia } \\
\text { hippophaecolus }\end{array}$ & $\begin{array}{c}1.00 \mathrm{E}- \\
86\end{array}$ \\
\hline EhipCSP16 & c8553.graph_c0 & 1186 & 384 & 939.550 & $\begin{array}{c}\text { chemosensory } \\
\text { protein } 16\end{array}$ & AOG12900.1 & $\begin{array}{c}\text { Eogystia } \\
\text { hippophaecolus }\end{array}$ & $\begin{array}{c}5.00 \mathrm{E}- \\
85\end{array}$ \\
\hline EhipCSP17 & c8432.graph_c0 & 686 & 384 & 2513.946 & $\begin{array}{c}\text { chemosensory } \\
\text { protein } 17\end{array}$ & AOG12901.1 & $\begin{array}{c}\text { Eogystia } \\
\text { hippophaecolus }\end{array}$ & $\begin{array}{c}1.00 \mathrm{E}- \\
87\end{array}$ \\
\hline EhipCSP13 & c18139.graph_c0 & 861 & 366 & 9.290 & $\begin{array}{c}\text { chemosensory } \\
\text { protein } 13\end{array}$ & AOG12897.1 & $\begin{array}{c}\text { Eogystia } \\
\text { hippophaecolus }\end{array}$ & $\begin{array}{c}2.00 \mathrm{E}- \\
82\end{array}$ \\
\hline EhipCSP9 & c23028.graph_c0 & 1400 & 435 & 72.606 & $\begin{array}{c}\text { chemosensory } \\
\text { protein9 }\end{array}$ & AOG12893.1 & $\begin{array}{c}\text { Eogystia } \\
\text { hippophaecolus }\end{array}$ & $\begin{array}{c}7.00 \mathrm{E}- \\
86\end{array}$ \\
\hline EhipCSP7 & c19136.graph_c0 & 1192 & 336 & 2.634 & $\begin{array}{c}\text { chemosensory } \\
\text { protein7 }\end{array}$ & AOG12891.1 & $\begin{array}{c}\text { Eogystia } \\
\text { hippophaecolus }\end{array}$ & $\begin{array}{c}1.00 \mathrm{E}- \\
58\end{array}$ \\
\hline EhipCSP1 & c14432.graph_c0 & 654 & 378 & 2921.079 & $\begin{array}{c}\text { chemosensory } \\
\text { protein } 1\end{array}$ & AOG12885.1 & $\begin{array}{c}\text { Eogystia } \\
\text { hippophaecolus }\end{array}$ & $\begin{array}{c}8.00 \mathrm{E}- \\
86\end{array}$ \\
\hline EhipCSP2 & c17913.graph_c0 & 418 & 213 & 5.381 & $\begin{array}{c}\text { chemosensory } \\
\text { protein2 }\end{array}$ & AOG12886.1 & $\begin{array}{c}\text { Eogystia } \\
\text { hippophaecolus }\end{array}$ & $\begin{array}{c}1.00 \mathrm{E}- \\
33\end{array}$ \\
\hline EhipCSP6 & c16159.graph_c0 & 1542 & 375 & 3977.722 & $\begin{array}{c}\text { chemosensory } \\
\text { protein6 }\end{array}$ & AOG12890.1 & $\begin{array}{c}\text { Eogystia } \\
\text { hippophaecolus }\end{array}$ & $\begin{array}{c}6.00 \mathrm{E}- \\
77\end{array}$ \\
\hline \multicolumn{9}{|c|}{ Odorant receptor } \\
\hline EhipOR15 & c49610.graph_c0 & 244 & 0 & 0.000 & $\begin{array}{c}\text { odorant } \\
\text { receptor15 }\end{array}$ & AOG12918.1 & $\begin{array}{c}\text { Eogystia } \\
\text { hippophaecolus }\end{array}$ & $\begin{array}{c}2.00 \mathrm{E}- \\
28\end{array}$ \\
\hline Ehip0R32 & c36330.graph_c0 & 335 & 270 & 0.417 & $\begin{array}{c}\text { odorant } \\
\text { receptor } 32\end{array}$ & AOG12937.1 & $\begin{array}{c}\text { Eogystia } \\
\text { hippophaecolus }\end{array}$ & $\begin{array}{l}1.00 \mathrm{E}- \\
72\end{array}$ \\
\hline EhipPR2 & c4712.graph_c0 & 273 & 186 & 0.000 & $\begin{array}{l}\text { pheromone } \\
\text { receptor2 }\end{array}$ & AOG12919.1 & $\begin{array}{c}\text { Eogystia } \\
\text { hippophaecolus }\end{array}$ & $\begin{array}{c}3.00 \mathrm{E}- \\
38\end{array}$ \\
\hline \multicolumn{9}{|c|}{ Ionotropic receptor } \\
\hline EhipIR25a & c33519.graph_c0 & 326 & 180 & 0.429 & $\begin{array}{c}\text { ionotropic } \\
\text { receptor } 25 \mathrm{a}\end{array}$ & AOG12847.1 & $\begin{array}{c}\text { Eogystia } \\
\text { hippophaecolus }\end{array}$ & $\begin{array}{c}8.00 \mathrm{E}- \\
67\end{array}$ \\
\hline EhipIR12 & c50725.graph_c0 & 413 & 360 & 0.339 & $\begin{array}{l}\text { ionotropic } \\
\text { receptor }\end{array}$ & AIG51922.1 & $\begin{array}{c}\text { Helicoverpa } \\
\text { armigera }\end{array}$ & $\begin{array}{c}3.00 \mathrm{E}- \\
63\end{array}$ \\
\hline $\begin{array}{c}\text { EhiplR75p1- } \\
\text { 1(13) }\end{array}$ & c6710.graph_c0 & 874 & 768 & 0.587 & $\begin{array}{c}\text { ionotropic } \\
\text { receptor } 75 \mathrm{p} 1\end{array}$ & AMM70652.1 & $\begin{array}{l}\text { Heliconius } \\
\text { melpomene }\end{array}$ & $\begin{array}{c}4.00 \mathrm{E}- \\
124\end{array}$ \\
\hline $\begin{array}{l}\text { EhipIR } \\
\text { IR75p1- } \\
\text { 2(14) }\end{array}$ & c12066.graph_c0 & 777 & 594 & 1.020 & $\begin{array}{l}\text { ionotropic } \\
\text { receptor }\end{array}$ & AIG51922.1 & $\begin{array}{c}\text { Helicoverpa } \\
\text { armigera }\end{array}$ & $\begin{array}{c}3.00 \mathrm{E}- \\
103\end{array}$ \\
\hline EhipIR76b & c50176.graph_c0 & 336 & 135 & 0.277 & $\begin{array}{c}\text { ionotropic } \\
\text { receptor 76b }\end{array}$ & AOG12850.1 & $\begin{array}{c}\text { Eogystia } \\
\text { hippophaecolus }\end{array}$ & $\begin{array}{c}8.00 \mathrm{E}- \\
43\end{array}$ \\
\hline EhipIR15 & c4645.graph_c0 & 260 & 132 & 0.000 & $\begin{array}{l}\text { ionotropic } \\
\text { receptor }\end{array}$ & AIG51915.1 & $\begin{array}{c}\text { Helicoverpa } \\
\text { armigera }\end{array}$ & $\begin{array}{c}7.00 \mathrm{E}- \\
12\end{array}$ \\
\hline EhipIR8a & c50367.graph_c0 & 223 & 147 & 0.000 & $\begin{array}{l}\text { ionotropic } \\
\text { receptor } 8 a\end{array}$ & AOG12845.1 & $\begin{array}{c}\text { Eogystia } \\
\text { hippophaecolus }\end{array}$ & $\begin{array}{c}1.00 \mathrm{E}- \\
42\end{array}$ \\
\hline \multicolumn{9}{|c|}{ Gustatory receptor } \\
\hline EhipGR 14 & c27065.graph_c0 & 510 & 153 & 0.822 & $\begin{array}{l}\text { gustatory } \\
\text { receptor } 8\end{array}$ & NP_001124344.1 & Bombyx mori & $\begin{array}{c}8.00 \mathrm{E}- \\
32\end{array}$ \\
\hline EhipGR15 & c18526.graph_c0 & 1780 & 1401 & 3.102 & $\begin{array}{l}\text { gustatory } \\
\text { receptor }\end{array}$ & AGA04648.1 & $\begin{array}{c}\text { Helicoverpa } \\
\text { armigera }\end{array}$ & 0 \\
\hline EhipGR16 & c5431.graph_c0 & 338 & 285 & 0.814 & $\begin{array}{c}\text { Gustatory } \\
\text { receptor } 46\end{array}$ & KOB66549.1 & $\begin{array}{c}\text { Operophtera } \\
\text { brumata }\end{array}$ & $\begin{array}{c}2.00 \mathrm{E}- \\
08\end{array}$ \\
\hline EhipGR7 & c9964.graph_c0 & 382 & 171 & 0.488 & $\begin{array}{l}\text { gustatory } \\
\text { receptor } 7\end{array}$ & AOG12966.1 & $\begin{array}{c}\text { Eogystia } \\
\text { hippophaecolus }\end{array}$ & $\begin{array}{c}1.00 \mathrm{E}- \\
32\end{array}$ \\
\hline EhipGR17 & c8069.graph_c0 & 1011 & 858 & 0.645 & $\begin{array}{l}\text { gustatory } \\
\text { receptor } 7\end{array}$ & DAA06374.1 & Bombyx mori & $\begin{array}{c}2.00 \mathrm{E}- \\
21\end{array}$ \\
\hline
\end{tabular}


EhipGR18 c34087.graph_c0

285

225

0.491

1792

1458

0.832

Sensory neuron membrane protein

EhipSNMP1 c9735.graph_c0

EhipSNMP2 c21118.graph_c0

1791

1566

5.855
$1668 \quad 10.713$

Odorant degrading enzyme

EhipODE1

c24925.graph_c1

5053

$354 \quad 13.465$

EhipODE2 c19816.graph_c0

938

354

EhipODE3 c13543.graph_c0

1919

1635

3.789

2481

1638

4.095

EhipODE4 c22117.graph_c0

2481

EhipODE5 c21202.graph_c0

1919

173

$1731 \quad 842.359$

171

c41817.graph_c0

484
EhipAES1

1760

EhipAES2

c24294.graph_c1

900

2110

1440

EhipAES3

c19867.graph_c0

431

297

EhipAES4 c28951.graph_c0

431

EhipAES5 c36194.graph_c0

492

480

EhipAES6

2460

1602

2.071

0.649

0.189

\subsection{3}

13.445

(1)

5.026

\section{gustatory \\ receptor 3}

sensory

neuron

membrane

protein 1

sensory

neuron

membrane

protein 2

\begin{tabular}{|c|c|c|c|}
\hline $\begin{array}{c}\text { odorant } \\
\text { degrading } \\
\text { enzyme CXE9 }\end{array}$ & All21983.1 & $\begin{array}{l}\text { Sesamia } \\
\text { inferens }\end{array}$ & 0 \\
\hline ODE & JAP88603.1 & $\begin{array}{l}\text { Conogethes } \\
\text { punctiferalis }\end{array}$ & $\begin{array}{c}2.00 \mathrm{E}- \\
50\end{array}$ \\
\hline $\begin{array}{c}\text { Odorant } \\
\text { degrading } \\
\text { nzyme CXE20 }\end{array}$ & KOB74700.1 & $\begin{array}{c}\text { Operophtera } \\
\text { brumata }\end{array}$ & $\begin{array}{c}2.00 \mathrm{E}- \\
152\end{array}$ \\
\hline $\begin{array}{c}\text { odorant } \\
\text { degrading } \\
\text { nzyme CXE10 }\end{array}$ & All21984.1 & $\begin{array}{l}\text { Sesamia } \\
\text { inferens }\end{array}$ & 0 \\
\hline $\begin{array}{c}\text { odorant } \\
\text { degrading } \\
\text { enzyme CXE5 }\end{array}$ & All21981.1 & $\begin{array}{l}\text { Sesamia } \\
\text { inferens }\end{array}$ & 0 \\
\hline
\end{tabular}

enzyme CXE5

$\begin{array}{cc}\text { AJD81596.1 } & \begin{array}{c}\text { Helicoverpa } \\ \text { assulta }\end{array}\end{array}$

$\begin{array}{lll}\text { AOG12884.1 Eogystia } & 0\end{array}$

hippophaecolus

$\begin{array}{lll}\text { AOG12883.1 } & \text { Eogystia } & 0\end{array}$

hippophaecolus

0

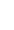




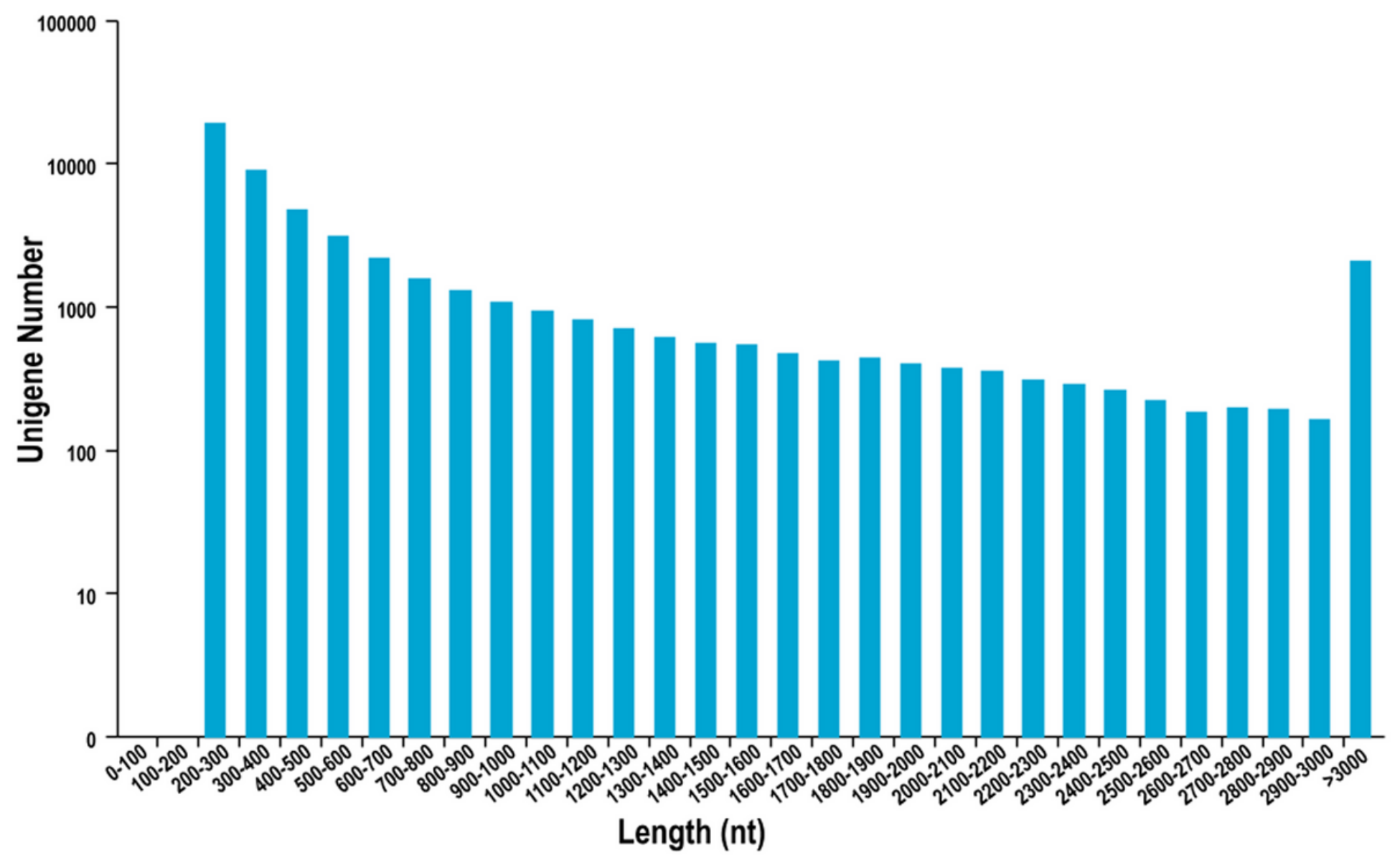

Figure 1

Length distribution of unigenes assembled from the E. hippophaecolus sex pheromone gland transcriptome. 


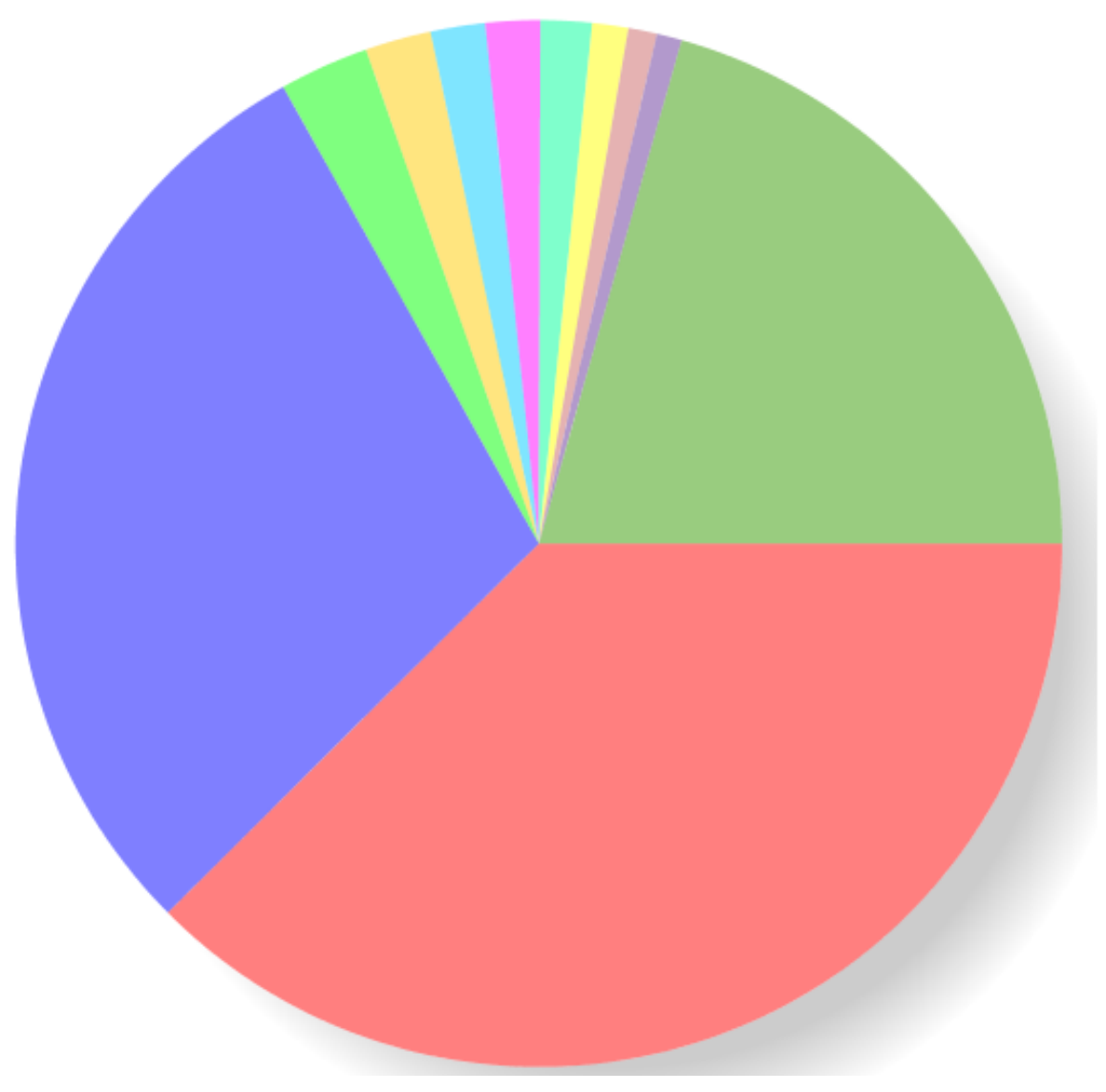

Bombyx mori 37.54\%

Danaus plexippus $29.3 \%$

Branchiostoma floridae $2.76 \%$

Papilio xuthus 2.04\%

Tribolium castaneum $1.69 \%$

Saccoglossus kowalevskii $1.68 \%$

Acyrthosiphon pisum $1.59 \%$

Solenopsis invicta $1.11 \%$

Stegodyphus mimosarum $0.88 \%$

Diaphorina citri $0.78 \%$

Other $20.59 \%$

Figure 2

BLASTx analysis of identified unigenes with known homologs from other species. 


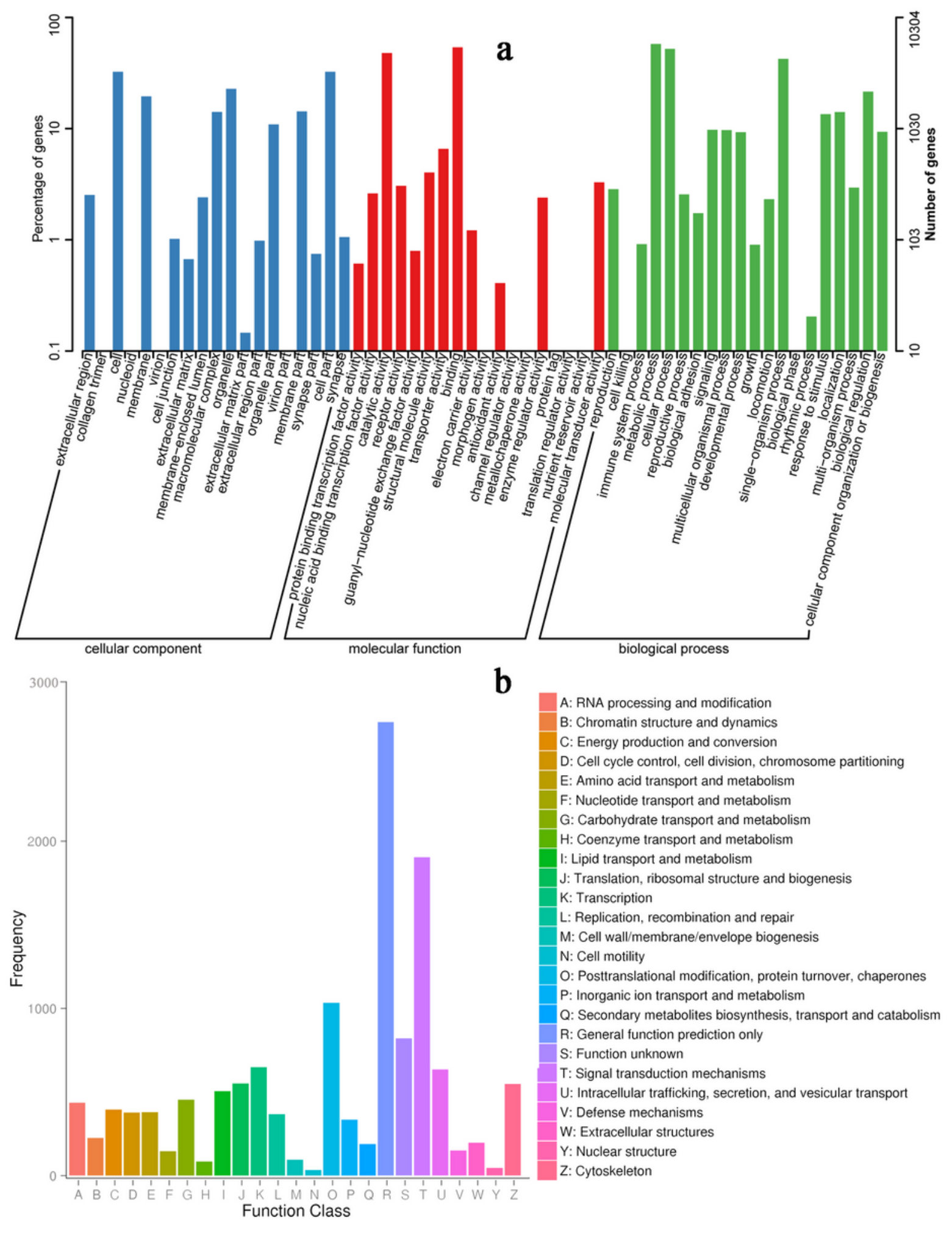

Figure 3

GO gene function classification and KOG function classification. (a) GO classification. (b) KOG function classification. 


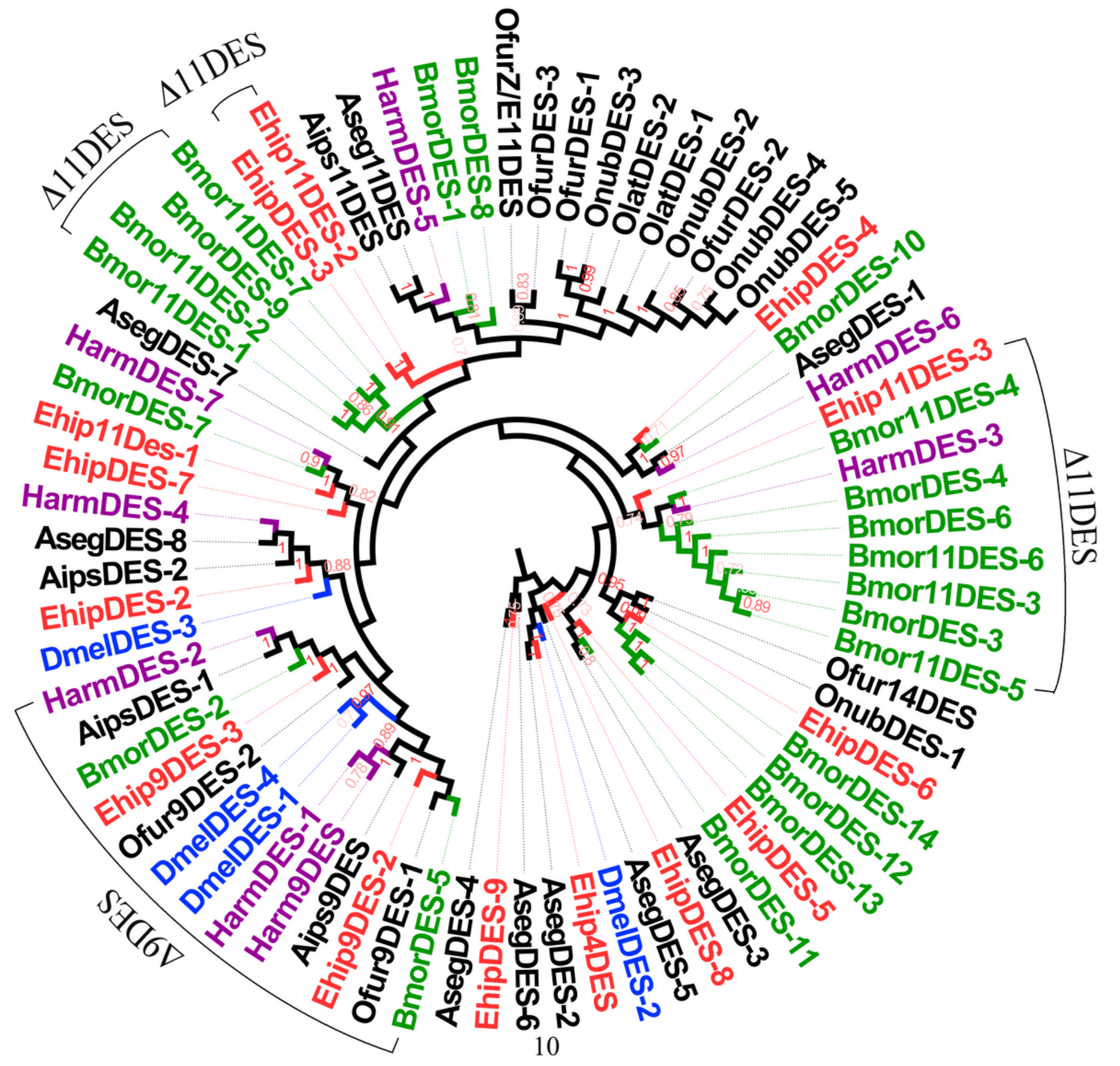

Figure 4

Neighbor-joining phylogenetic tree of acyl-CoA desaturases (DESs). 


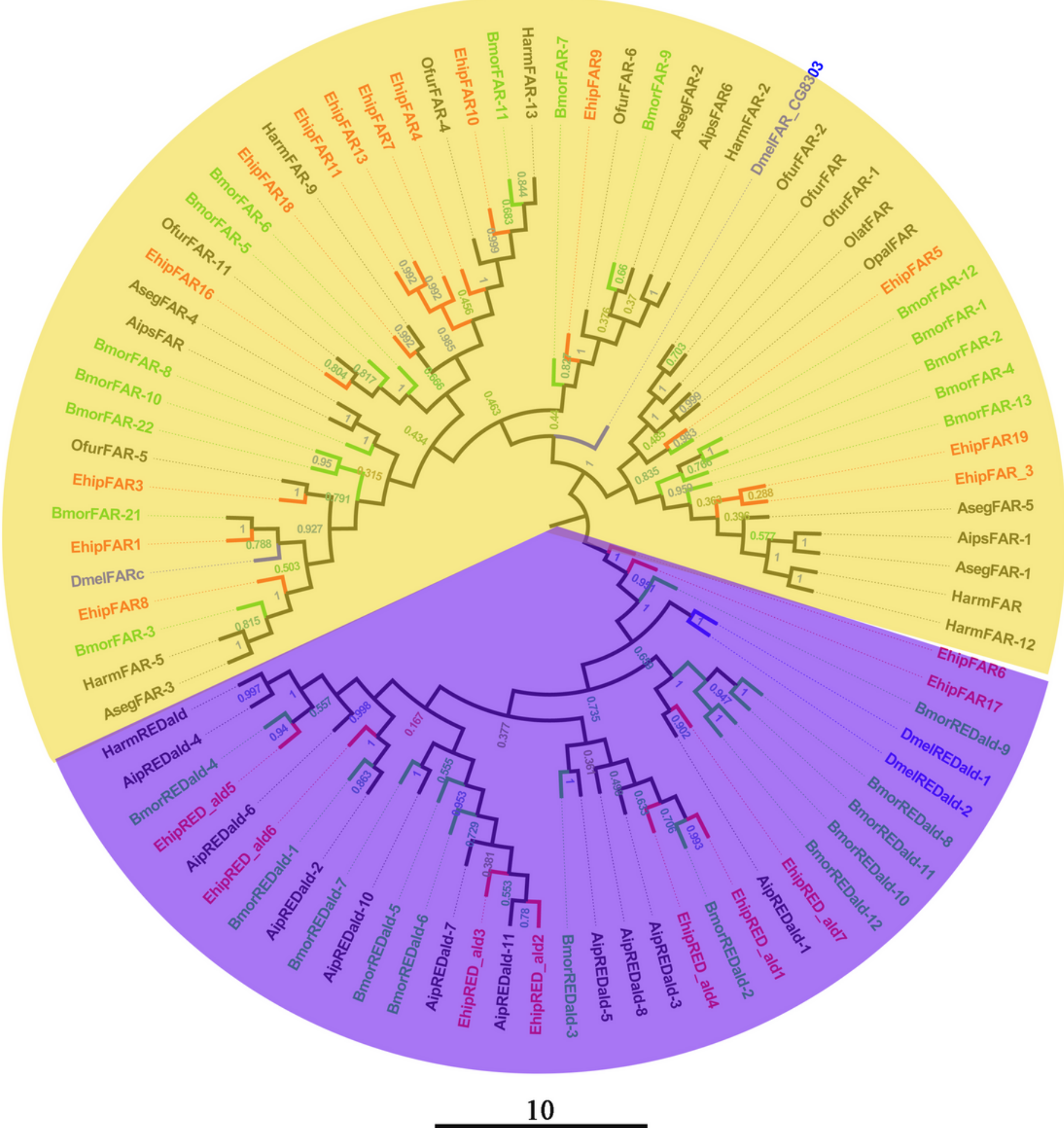

Figure 5

Neighbor-joining phylogenetic tree of reductases (REDs). 


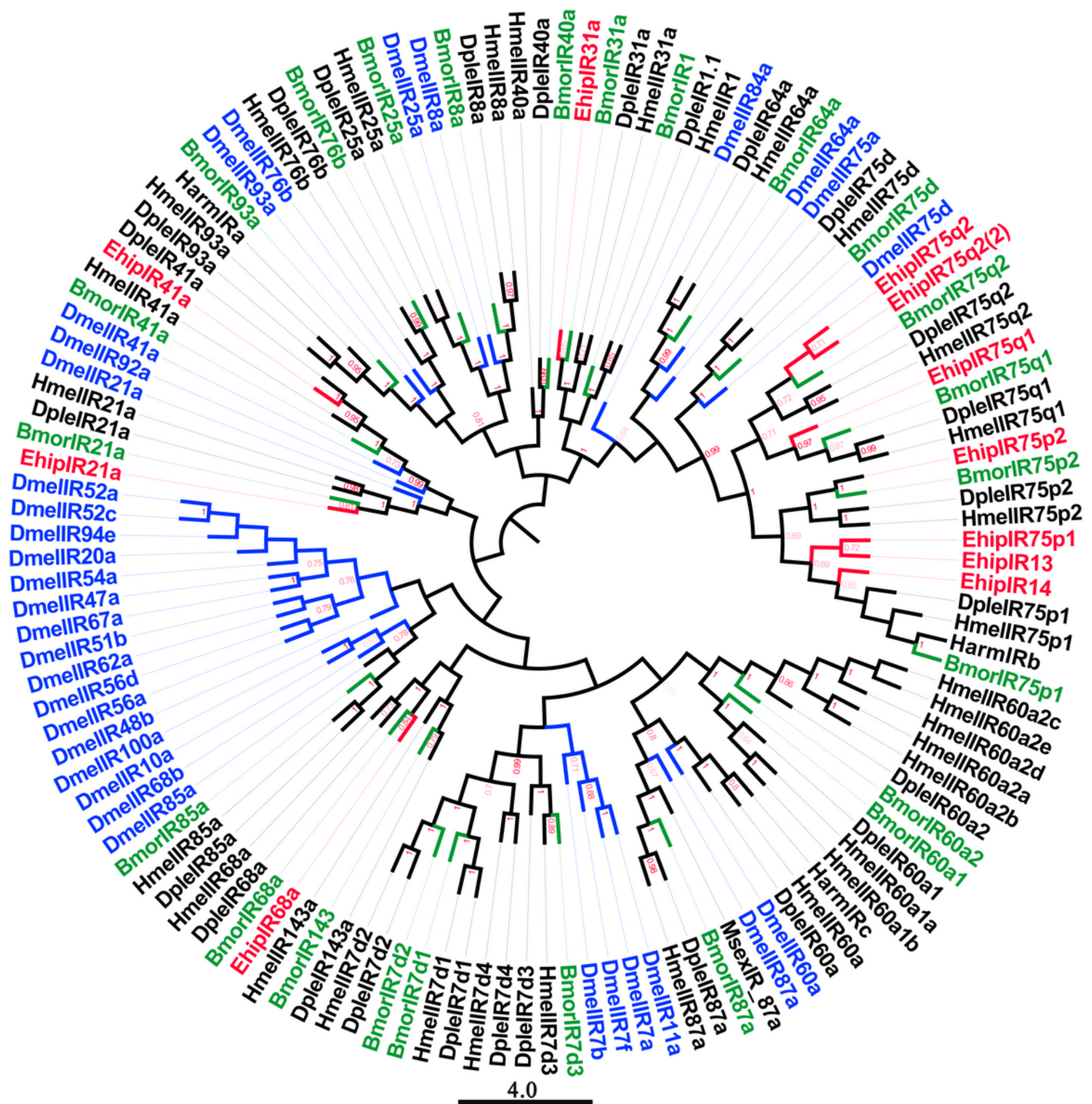

Figure 6

Neighbor-joining phylogenetic tree of ionotropic receptors(IRs). 


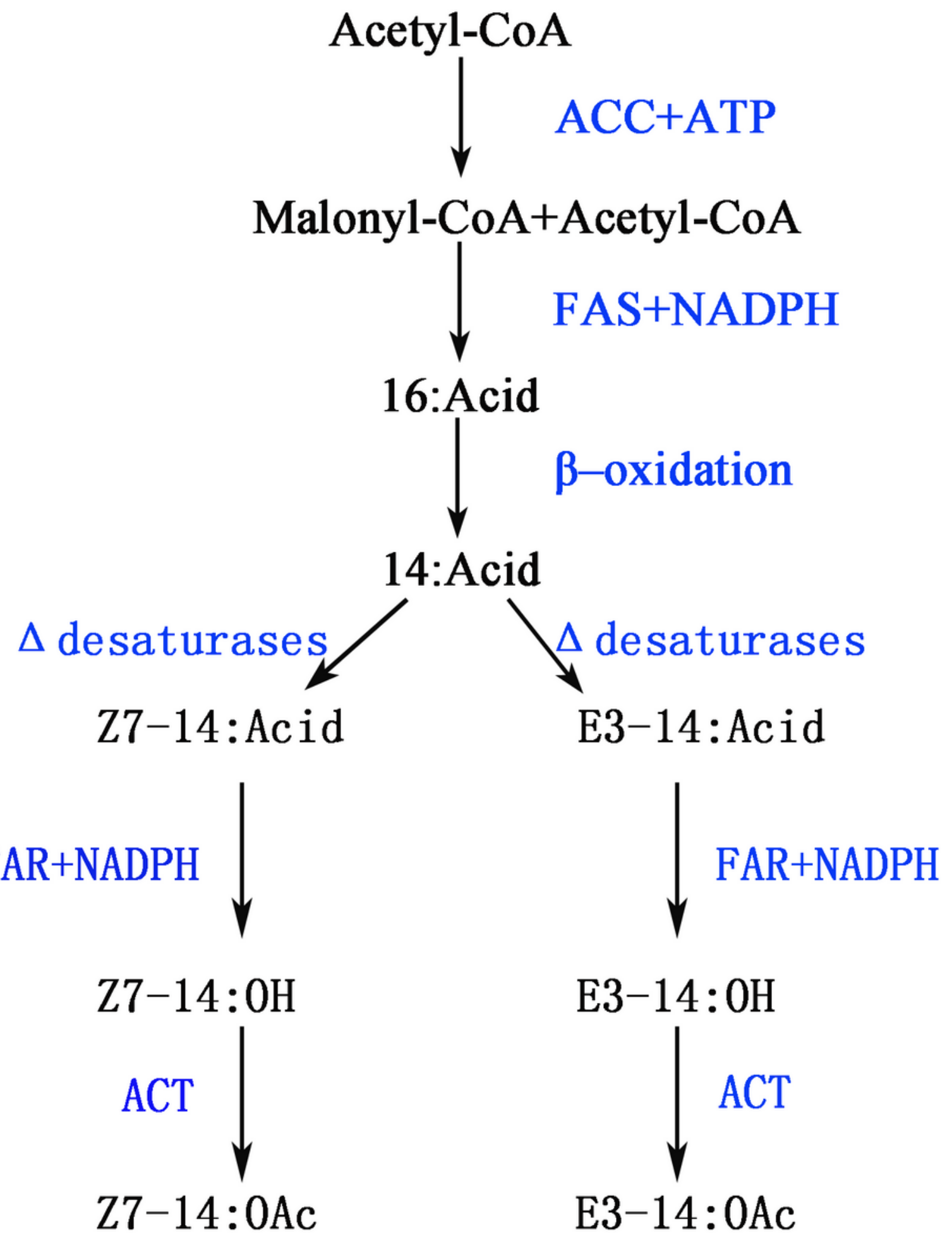

Figure 7

Biosynthesis pathway for Z7-14:Ac and E3-14:Ac in E. hippophaecolus.

且

Figure 8 
Photograph showing the E. hippophaecolus female sex pheromone glands. The magnified view on the right shows the sclerotized ovipositor valves (1), the pheromone gland (2), and the sclerotized cuticle (3) that has been removed.

\section{Supplementary Files}

This is a list of supplementary files associated with this preprint. Click to download.

- Additionalfile3njAES.tif

- additionalfile1Top100FPKM.docx

- Additionalfile4.doc

- additionalfile2.doc 